\title{
Synthesis and Anti-herpetic Activity of Phosphoramidate ProTides
}

\author{
Munmun Maiti, ${ }^{[\mathrm{a}]}$ Leentje Persoons, $^{[\mathrm{b}]}$ Graciela Andrei, $^{[\mathrm{b}]}$ Robert Snoeck, ${ }^{[\mathrm{b}]}$ Jan Balzarini, ${ }^{[\mathrm{b}]}$ and \\ Piet Herdewijn ${ }^{*[a]}$
}

Dedicated to Professor Fritz Eckstein on the occasion of his 80th birthday.

\begin{abstract}
Among the many prodrug approaches aimed at delivering nucleoside monophosphates into cells, the phosphoramidate ProTide approach is one that has shown success, which has made it possible for some of the phosphoramidates to enter into clinical trials. Herein, we report the synthesis and antiviral activity of a series of phosphoramidate ProTides designed to bypass the thymidine kinase (TK) dependence of the parent nucleoside analogues. Phosphoramidate derivatives of $(E)-5$-(2bromovinyl)-2'-deoxyuridine (BVDU) that contain L-alanine or pivaloyloxymethyl iminodiacetate (IDA-POM) exhibit anti-HSV-
\end{abstract}

1 and anti-VZV activity in cell cultures, but they largely lost antiviral potency against TK-deficient virus strains. Among deazapurine nucleosides and their phosphoramidate derivatives, the 7-deazaadenine containing nucleosides and their phosphoramidate triester derivatives showed weak antiviral activity against VZV. Apparently, intracellular nucleotide delivery with these phosphoramidates is partly successful. However, none of the compound prodrugs showed superior activity to their parent drugs.

\section{Introduction}

Today, around 50 antiviral drugs are on the market that have been approved for the treatment of several virus infections. ${ }^{[1]}$ Of those 50 , only eight (Figure 1) are licensed to be used as anti-herpetic drugs, among them (E)-5-(2-bromovinyl)-2'-deoxyuridine (BVDU, Brivudin), ${ }^{[2]}$ which is used against herpes simplex virus-1 (HSV-1) and varicella-zoster virus (VZV). The selectivity of BVDU toward HSV-1 and VZV depends primarily on a specific sequential phosphorylation by the virus-encoded thymidine/thymidylate kinase (TK) to form the $5^{\prime}$-monoand $5^{\prime}$-diphosphate derivatives. ${ }^{[2-4]}$ After further phosphorylation into the $5^{\prime}$-triphosphate (BVDU-TP) by cellular kinases,

\section{[a] M. Maiti, Prof. P. Herdewijn}

Laboratory of Medicinal Chemistry

Rega Institute for Medical Research, KU Leuven

Minderbroedersstraat 10, 3000 Leuven (Belgium)

E-mail:Piet.Herdewijn@rega.kuleuven.be

[b] L. Persoons, Prof. G. Andrei, Prof. R. Snoeck, Prof. J. Balzarini Laboratory of Virology and Chemotherapy Rega Institute for Medical Research, KU Leuven Minderbroedersstraat 10, 3000 Leuven (Belgium)

Supporting information for this article is available on the WWW under http://dx.doi.org/10.1002/cmdc.201300035.
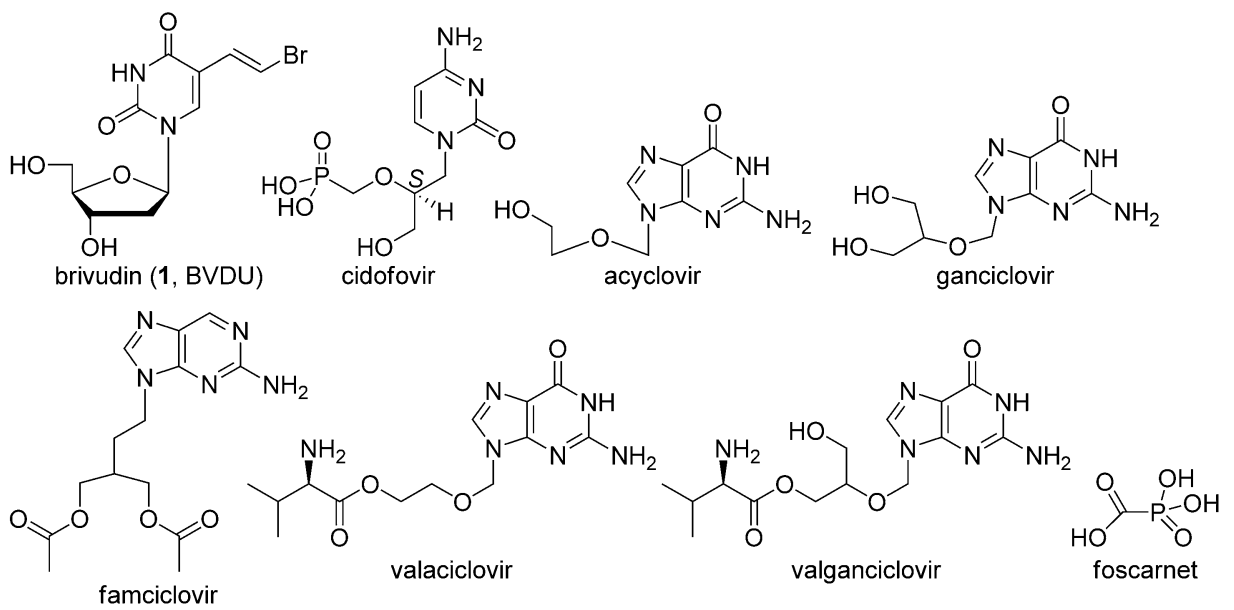

Figure 1. Marketed anti-herpetic drugs for clinical use.

BVDU-TP interferes with the viral DNA polymerase as a competitive/alternative substrate and thus interferes with the viral DNA synthesis. ${ }^{[3]}$

In most cases, like BVDU, the active form of a nucleoside drug is the $5^{\prime}-O$-triphosphate derivative (functioning as a DNA chain terminator/polymerase inhibitor). ${ }^{[5]}$ The formation of the triphosphate occurs in three steps, and the first step, responsible for the formation of the nucleoside monophosphate, is often considered as the rate-limiting step, which limits the therapeutic potential of many modified nucleoside analogues. $^{[6]}$ Moreover, drug-resistant virus strains are appearing with the continuous use of drugs: for example, BVDU-resistant HSV-1 isolates have been identified and found to be associated 
with a decreased level of viral thymidine kinase activity. ${ }^{[7]}$ Therefore, direct administration of the preformed nucleoside monophosphate (nucleotide) would be preferred in order to bypass the rate-limiting step in the nucleoside metabolism. However, being charged under physiological conditions, nucleoside monophosphates show poor, if any, cell-membrane permeability and are also highly susceptible to dephosphorylation by phosphatases. Therefore, several neutral and membrane-permeable pronucleotides (prodrugs) ${ }^{[8]}$ have been developed over the past decades. One of them is the phosphoramidate prodrug introduced by McGuigan and co-workers in the $1990 s,{ }^{[9,10]}$ which relies on intracellular enzymatic activation of the prodrug to release the desired nucleoside monophosphate inside the cell. The postulated mechanism of phosphoramidate activation has been explained in several review articles. ${ }^{[10-12]}$ With this phosphoramidate triester ProTide approach, at least 9131, thymectacin (NB1011), and stampidine) have entered clinical trials. ${ }^{[12]}$

Viewing this success, we were interested in synthesizing a series of aryloxy phosphoramidate ProTide analogues of BVDU and of several deazaadenine nucleosides (Figure 2). BVDU is an ideal prototype to test a new nucleotide-prodrug strategy, because HSV TK ${ }^{-}$cells are available, in which BVDU is not phosphorylated into its monophosphate (MP) form. 2'-Deoxynucleosides with a deazaadenine base moiety (2-5) have not been described as antiviral nucleoside analogues, which may be due to lack of their intracellular phosphorylation. Therefore, it is interesting to apply the ProTide approach, four different aryloxy triester phosphoramidates (GS-9140, GS-

which may shed light on this hypothesis, so that the modified nucleoside monophosphate is released intracellularly. Apart from using the methyl ester of L-alanine (as previously synthesized by Harris et al. $)^{[13]}$ as the amidate counterpart, we have also synthesized the methyl and pivaloyloxymethyl (POM) esters of iminodiacetic acid (IDA) ${ }^{[14]}$ to evaluate the comparative antiviral activities. As promoieties, $\mathrm{POM}^{[15]}$ and isopropyloxymethylcarbonyl $(P O C)^{[16]}$ have previously been introduced successfully to increase the oral bioavailability of the parent drugs. For example: adefovir dipivoxil ${ }^{[17,18]}$ and tenofovir disoproxil fumarate $(\mathrm{TDF})^{[19]}$ are two FDA-approved POM- or POCderived antiviral prodrugs on the market, along with some POM-derived antibiotics ${ }^{[18]}$ and anticancer ${ }^{[20]}$ prodrugs. The diaIkyl amine IDA has been selected here because we have shown that IDA-dAMP (a phosphoramidate conjugate of IDA and deoxyadenosine monophosphate (dAMP)) can act as a direct substrate for viral polymerases (IDA acts as a good leaving group) in an enzymatic assay and can incorporate the nucleotide moiety into DNA (that is, no triphosphate formation is required) ${ }^{[14]}$ We tested the hypothesis that after the first esterase-mediated cleavage of the carboxyl ester group and the subsequent release of the aryl alcohol, the phosphoramidic acid formed could be directly recognized by the viral polymerase, to show an antiviral effect. Alternatively, intracellular cleavage of the $\mathrm{P}-\mathrm{N}$ bond by a nonenzymatic mechanism may bypass the final step of metabolic activation in the pronucleotide approach of McGuigan, Wagner and their respective coworkers, that is, the action of the phosphoramidase enzyme to cleave the $\mathrm{P}-\mathrm{N}$ bond. The presence of the phosphoramidase enzyme is considered to be celltype specific. ${ }^{[21]}$ A pure chemical degradation mechanism of the prodrug could have the advantage of a cell-line-independent mechanism of nucleotide delivery. Based on these successful applications, we were interested to pursue a prodrug approach by combining the POM and IDA
moieties for the intracellular de1 2 3 4 5

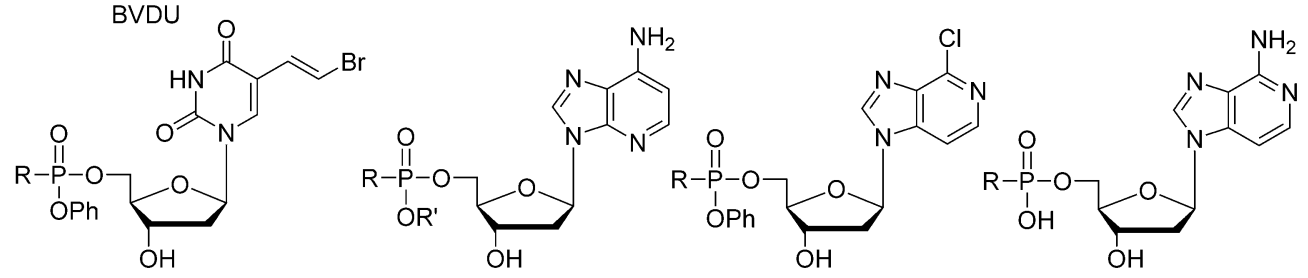
1a $\mathrm{R}=\mathrm{L}-\mathrm{Ala}-\mathrm{Me}$ $1 \mathrm{~b} R=$ IDA-Me 1c $R=$ IDA-POM 2a $R=L-A l a-M e, R^{\prime}=P h$ 2b $R=I D A-M e, R^{\prime}=P h$ 2c $R=$ IDA-POM, $R^{\prime}=P h$ 3a $\mathrm{R}=\mathrm{L}-\mathrm{Ala}-\mathrm{Me}$ 3b $R=$ IDA-POM 4a $\mathrm{R}=\mathrm{L}-\mathrm{Asp}-\mathrm{Me}$ 2d $R=$ L-Asp-Me, R' = H
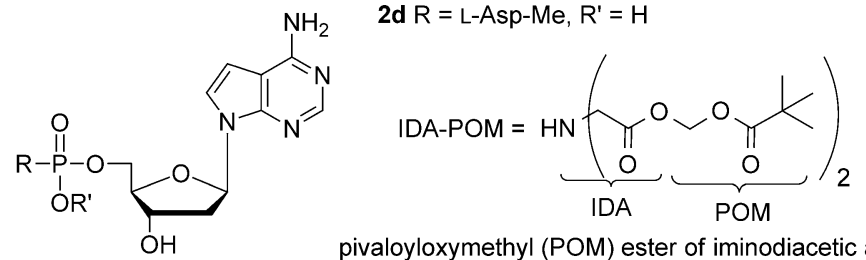

pivaloyloxymethyl (POM) ester of iminodiacetic acid

5a $\mathrm{R}=\mathrm{L}-\mathrm{Ala}-\mathrm{Me}, \mathrm{R}^{\prime}=\mathrm{Ph}$

5b $\mathrm{R}=\mathrm{IDA}-\mathrm{POM}, \mathrm{R}^{\prime}=\mathrm{Ph}$

5c $R=L-A s p-M e, R^{\prime}=H$

Figure 2. Aryloxy phosphoramidate ProTide analogues and the corresponding nucleosides used in this study. livery of our nucleotides. Herein, we report the synthesis of a series of aryloxy phosphoramidate ProTide analogues and present their antiviral activity. We also present the antiviral activity of L-aspartic acid phosphoramidate diesters (containing a negatively charged phosphate group) of deazaadenine nucleosides. This concept was first developed by Wagner and coworkers. $^{[22,23]}$ The purpose of choosing aspartic acid here is that Asp-dAMP (a phosphoramidate conjugate) has also been shown to be a direct substrate 
for viral polymerases. ${ }^{[24]}$ In addition, we have shown that the aspartic acid phosphoramidate analogues of certain deazaadenine nucleosides could undergo spontaneous $\mathrm{P}-\mathrm{N}$ bond cleavage to release the desired modified nucleotides. ${ }^{[25]}$

\section{Results and Discussion}

\section{Chemistry}

The synthesis of POM-protected iminodiacetic acid hydrochloride salt 9 was carried out by starting with commercially available IDA (6), as shown in Scheme 1. After the protection of the

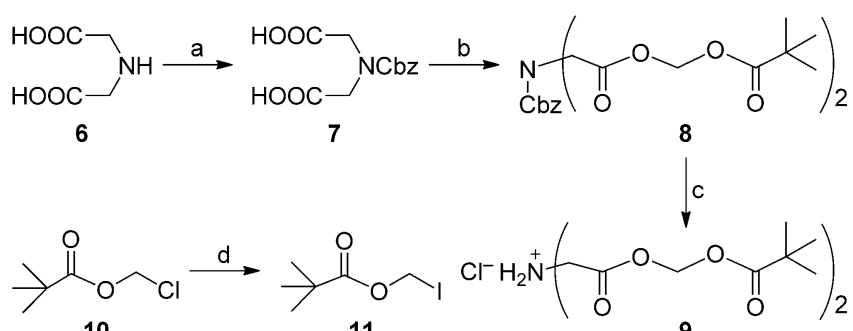

Scheme 1. Synthesis of the pivaloyloxymethyl iminodiacetate (IDA-POM) hydrochloride salt 9. Reagents and conditions: a) $2 \mathrm{M} \mathrm{NaOH}$, benzyl chloroformate, $\mathrm{RT}, 4 \mathrm{~h}$; b) $\mathrm{Ag}_{2} \mathrm{CO}_{3}$, pivaloyloxymethyl iodide (11), dry DMF, RT, overnight; c) $\mathrm{H}_{2}, 10 \% \mathrm{Pd} / \mathrm{C}, \mathrm{MeOH}, 5 \mathrm{~N} \mathrm{HCl}$ in $i \mathrm{PrOH}, \mathrm{RT}, 4 \mathrm{~h}$; d) $\mathrm{Nal}, \mathrm{MeCN}, 30^{\circ} \mathrm{C}$, overnight.

imino nitrogen atom by using the carboxybenzyl (Cbz) group, ${ }^{[26]}$ the carboxylic acid groups were protected with the POM moiety by using pivaloyloxymethyl iodide (POM-I, 11), ${ }^{[27]}$ which was prepared from pivaloyloxymethyl chloride (10) and stored at $-20^{\circ} \mathrm{C}$ before use. As a base, both silver carbonate ${ }^{[28]}$ and cesium carbonate were tried. The yield of the reaction was found to be better with silver carbonate. Finally, the $\mathrm{Cbz}$ group was removed under $\mathrm{a} \mathrm{H}_{2}$ atmosphere in the presence of $\mathrm{Pd} / \mathrm{C}$ and alcoholic hydrochloric acid to yield the POM ester of IDA in the form of the hydrochloride salt $\mathbf{9}$.

All phenoxy phosphoramidate triesters (1 $\mathbf{a}-\mathbf{c}, \mathbf{2} \mathbf{a}-\mathbf{c}, \mathbf{3} \mathbf{a}, \mathbf{b}$, and $\mathbf{5} \mathbf{a}, \mathbf{b}$; Figure 2 ) were synthesized by phosphorochloridate chemistry by using an optimized method, as described by Lehsten et al. ${ }^{[29]}$ The optimum reaction conditions (in ref. [29]) were found to be as follows: 2.5 equiv phenyl dichlorophosphate $\left(\mathrm{PhOP}(\mathrm{O}) \mathrm{Cl}_{2}\right)$ with 3.5 equiv L-alanine methyl ester hydrochloride (1.4 equiv with respect to $\operatorname{PhOP}(\mathrm{O}) \mathrm{Cl}_{2}$ ) and 10 equiv $\mathrm{N}$ methylimidazole (NMI) in $\mathrm{CH}_{2} \mathrm{Cl}_{2}$. The temperature for the first step was -10 to $0{ }^{\circ} \mathrm{C}$, and for the second step was $-5^{\circ} \mathrm{C}$ to room temperature with more than $99 \%$ purity even on multigram scale. This method was first developed by McGuigan et al. ${ }^{[30]}$ with a stoichiometric amount of $\operatorname{PhOP}(\mathrm{O}) \mathrm{Cl}_{2}$ and an amino acid $\mathrm{HCl}$ salt in the presence of triethylamine at very low temperature $\left(-78^{\circ} \mathrm{C}\right)$. This was followed by a dry filtration step to remove the $\mathrm{Et}_{3} \mathrm{NHCl}$ salt, and the filtrate was used in the next step without further purification. The method optimized by Lehsten et al. offers advantages in reaction conditions, including the ability to perform the reaction at a temperature substantially higher than $-78^{\circ} \mathrm{C}$ and omission of the first filtration step. Therefore, we have chosen the method of Lehsten et al. to synthesize the series of phosphoramidate triesters (Scheme 2) and have also successfully employed the protocol

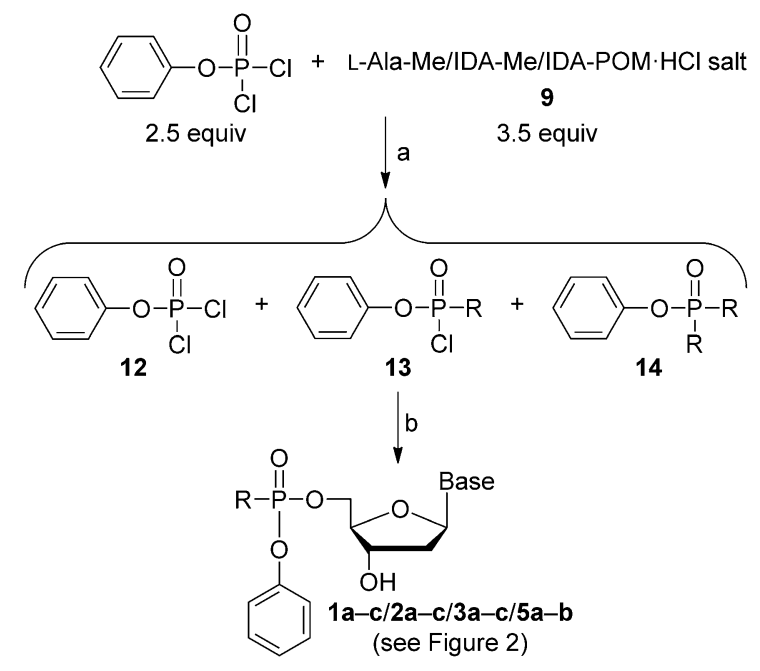

Scheme 2. Synthesis of aryloxy phosphoramidate ProTide analogues. Reagents and conditions: a) $\mathrm{N}$-methylimidazole, dry $\mathrm{CH}_{2} \mathrm{Cl}_{2},-15^{\circ} \mathrm{C} \rightarrow \mathrm{RT}$; b) requisite nucleoside $(1 / 2 / 3 / 5)$, dry $\mathrm{CH}_{2} \mathrm{Cl}_{2},-5^{\circ} \mathrm{C} \rightarrow \mathrm{RT}$.

to couple the secondary amine salts to the phosphate moiety by varying the reaction time and temperature (see the Experimental Section). The phosphoramidate analogues were purified by flash column chromatography (twice) and were fully characterized by spectroscopic and analytical techniques. The overall yields of the reactions are in the range of $25-70 \%$. ${ }^{31} \mathrm{P}$ NMR investigations of the phosphoramidates displayed the presence of two diastereomers resulting from the mixed phosphate stereochemistry.

The synthesis of the methylester-protected aspartic acid phosphoramidate diesters $\mathbf{2} \mathbf{d}, \mathbf{4 a}$, and $\mathbf{5 c}$ (Figure 2) was performed according to the method described by Wagner and coworkers $^{[23]}$ by starting from the nucleoside monophosphate and using dicyclohexylcarbodiimide (DCC)-mediated coupling. The synthetic protocol and characterization data for compounds $\mathbf{2}, \mathbf{5}, \mathbf{2} \mathrm{d}$, and $\mathbf{5 c}$ have previously been communicated in our earlier work. ${ }^{[25]}$ The synthesis of compounds $\mathbf{3}$ and $\mathbf{4}$ was carried out by following previously reported methods ${ }^{[31]}$ with optimization for some of the reaction steps. The phosphoramidate diester $4 \mathrm{a}$ was synthesized by the method reported in our earlier work. ${ }^{[25]}$ The synthetic steps and the characterization data are provided in the Supporting Information.

\section{Antiviral activity}

The modified nucleosides $\mathbf{1 - 5}$ and the corresponding ProTides $\mathbf{1} \mathbf{a}-\mathbf{5} \mathrm{c}$ have been evaluated for their potential inhibitory activity against a wide variety of DNA viruses in HEL cell cultures, including thymidine kinase deficient HSV-1 and VZV strains. As reference compounds, BVDU (1), Cidofovir, Acyclovir, and Ganciclovir were included (Tables 1 and 2). The ProTides of BVDU $1 \mathrm{a}\left(\mathrm{EC}_{50}:(0.3 \pm 0.1) \mu \mathrm{M}\right)$ and $1 \mathrm{c}\left(\mathrm{EC}_{50}:(1.1 \pm 0.4) \mu \mathrm{M}\right)$ exhibited 
potent anti-HSV-1 activity (being only three- to tenfold less effective than the parent BVDU compound) but, as is also the case for the parent compound, lost activity against thymidine kinase deficient $\left(\mathrm{TK}^{-}\right)$virus strains (Table 1). This seems to indicate a lack of appreciable intracellular nucleotide delivery for the BVDU-MP prodrugs and also supports the requirement for the presence of the virus-encoded thymidine kinase as the activating enzyme to obtain eventual antiviral activity. Compound $1 \mathrm{c}$ showed approximately fourfold-decreased activity against HSV1 when compared with the activity of compound $1 \mathbf{a}$, for which the antiviral activity was published previously and correlated well with our data. ${ }^{[13]}$ The decreased activity of compound $1 \mathrm{c}$ might be due to its higher lipophilicity, which could have posed a solubility problem in the biological assay medium. Alternatively, it could be that this compound is poorly processed by intracellular enzymes to release either the active nucleoside (BVDU, 1 ), or the nucleotide (BVDUmonophosphate) because the phosphoramidase enzyme is poorly expressed in the embryonic lung cell line that has been used for the assays. ${ }^{[1]}$ The poor activity might also be due to an insufficient kinetic profile of the phosphoramidic acid conjugates for viral polymerase for incorporation into a growing DNA chain and action as a chain terminator.

Compound $1 \mathrm{a} \quad\left(\mathrm{EC}_{50}: 0.21 \mu \mathrm{M}\right)$ and $1 \mathrm{c} \quad\left(\mathrm{EC}_{50}\right.$ : $0.34 \mu \mathrm{M}$ ) showed nearly 7- to 11-fold decreased activity in HEL cell cultures against varicella-zoster virus when compared with the activity of the drug/parent nucleoside BVDU (1, Table 2).
Table 1. Anti-HSV and anti-vaccinia activities and cytotoxicity of ProTide analogues in human embryonic lung (HEL) cell cultures.

\begin{tabular}{|c|c|c|c|c|c|}
\hline Compound & HSV-1 (KOS) & $\begin{array}{c}\mathrm{EC}_{50}[\mu \mathrm{M}]^{[\mathrm{a}]} \\
\text { HSV-1 } \mathrm{TK}^{-} \text {KOS ACV }\end{array}$ & HSV-2 (G) & VV & $\mathrm{MCC}[\mu \mathrm{M}]^{[\mathrm{b}]}$ \\
\hline Brivudin (1) & $0.1 \pm 0.06$ & 250 & 250 & 10 & $>250$ \\
\hline $1 \mathrm{a}$ & $0.3 \pm 0.1$ & $>20$ & $>20$ & $\geq 20$ & $\geq 100$ \\
\hline $1 \mathrm{~b}$ & $>100$ & $>100$ & $>100$ & $>100$ & $>100$ \\
\hline $1 \mathrm{c}$ & $1.1 \pm 0.4$ & $>4$ & $>4$ & $>4$ & 100 \\
\hline 2 & $>100$ & $>100$ & $>100$ & $>100$ & $>100$ \\
\hline $2 \mathrm{a}$ & $>100$ & $>100$ & $>100$ & $>100$ & $>100$ \\
\hline $2 b$ & $>100$ & $>100$ & $>100$ & $>100$ & $>100$ \\
\hline $2 c$ & $>20$ & $>20$ & $>20$ & $>20$ & 100 \\
\hline $2 d$ & $>100$ & $>100$ & $>100$ & $>100$ & $>100$ \\
\hline 3 & $>100$ & $>100$ & $>100$ & $>100$ & $>100$ \\
\hline $3 a$ & $>100$ & $>100$ & $>100$ & $>100$ & $>100$ \\
\hline $3 b$ & $>20$ & $>20$ & $>20$ & $>20$ & 100 \\
\hline 4 & $>100$ & $>100$ & $>100$ & $>100$ & $>100$ \\
\hline $4 a$ & $>100$ & $>100$ & $>100$ & $>100$ & $>100$ \\
\hline 5 & 100 & $\geq 100$ & $69 \pm 31$ & $>100$ & $>100$ \\
\hline $5 a$ & $>100$ & $>100$ & $>100$ & $>100$ & $>100$ \\
\hline $5 b$ & $>100$ & $>100$ & $>100$ & $>100$ & $\geq 100$ \\
\hline $5 c$ & $>100$ & $>100$ & $>100$ & $>100$ & $>100$ \\
\hline Cidofovir & 2 & 2 & 2 & 10 & $>250$ \\
\hline Acyclovir & 0.2 & 50 & 0.4 & $>250$ & $>250$ \\
\hline Ganciclovir & 0.02 & 14 & 0.02 & $>100$ & $>100$ \\
\hline
\end{tabular}

[a] Effective concentration required to inhibit virus-induced cytopathicity by $50 \%$. HSV-1: herpes simplex virus-1; HSV-2: herpes simplex virus-2; VV: vaccinia virus. [b] Minimum cytotoxic concentration or compound concentration required to result in a microscopically visible alteration of cell morphology.

However, almost equal $\mathrm{EC}_{50}$ values are obtained for the BVDU ProTides bearing an amino acid L-alanine methyl ester (1 a) and a secondary amine ester pivaloyloxymethyl iminodiacetate (1 c). Apparently, the amino acid can also be replaced by a sec-

Table 2. Antiviral activity of ProTide analogues against varicella-zoster virus (VZV) and cytomegalovirus (HCMV) in human embryonic lung (HEL) cell cultures.

\begin{tabular}{|c|c|c|c|c|c|c|c|}
\hline \multirow[t]{2}{*}{ Compound } & \multicolumn{2}{|c|}{ Anti-VZV EC $50[\mu \mathrm{M}]^{[\mathrm{a}]}$} & \multicolumn{2}{|c|}{ Cytotoxicity $[\mu \mathrm{M}]$} & \multicolumn{2}{|c|}{ Anti-HCMV EC ${ }_{50}[\mu \mathrm{M}]^{[a]}$} & \multirow{2}{*}{$\begin{array}{c}\text { Cytotoxicity }[\mu \mathrm{M}] \\
\mathrm{MCC}^{[\mathrm{b}]}\end{array}$} \\
\hline & $\mathrm{TK}^{+} \mathrm{VZV}$ strain OKA & $\mathrm{TK}^{-}$VZV strain 07-1 & $\mathrm{MCC}^{[\mathrm{b}]}$ & $\mathrm{CC}_{50}{ }^{[\mathrm{c}]}$ & AD-169 strain & Davis strain & \\
\hline Brivudin (1) & $0.03 \pm 0.007$ & $143 \pm 8.5$ & $>300$ & $201 \pm 47$ & $>100$ & $>100$ & $>100$ \\
\hline $1 \mathrm{a}$ & $0.21 \pm 0.02$ & $>20$ & 100 & $51.7 \pm 12$ & $>20$ & $>20$ & 100 \\
\hline $1 \mathrm{~b}$ & $>20$ & $>20$ & $\geq 100$ & - & $>100$ & $>100$ & $>100$ \\
\hline $1 \mathrm{c}$ & $0.34 \pm 0.08$ & 20 & 100 & $43 \pm 4.8$ & $>20$ & $>20$ & 100 \\
\hline 2 & $>100$ & $>100$ & $>100$ & - & $>100$ & $>100$ & $>100$ \\
\hline $2 a$ & $>100$ & $>100$ & $>100$ & - & $>100$ & $>100$ & $>100$ \\
\hline $2 b$ & $>20$ & $>100$ & $\geq 100$ & - & $>100$ & $>100$ & $>100$ \\
\hline $2 c$ & $>20$ & $>20$ & 100 & - & $>20$ & $>20$ & 100 \\
\hline $2 d$ & $>100$ & $>100$ & $>100$ & - & $>100$ & $>100$ & $>100$ \\
\hline 3 & $>100$ & $>100$ & $>100$ & - & $>100$ & $>100$ & $>100$ \\
\hline $3 a$ & $>100$ & $>100$ & $>100$ & - & $>100$ & $>100$ & $>100$ \\
\hline $3 b$ & $>100$ & $>100$ & $>100$ & - & $>100$ & $>100$ & $>100$ \\
\hline 4 & $>100$ & $>100$ & $>100$ & - & $>100$ & $>100$ & $>100$ \\
\hline $4 a$ & $>100$ & $>100$ & $>100$ & - & $>100$ & $>100$ & $>100$ \\
\hline 5 & $2.4 \pm 0.8$ & $20 \pm 8.3$ & $>100$ & $74 \pm 7.5$ & $>100$ & $>100$ & $>100$ \\
\hline $5 a$ & $68 \pm 31$ & $>100$ & $>100$ & - & $>100$ & $>100$ & $>100$ \\
\hline $5 b$ & $37.5 \pm 2$ & $87 \pm 12$ & $>100$ & - & $>100$ & $>100$ & $>100$ \\
\hline $5 c$ & $>100$ & $>100$ & $>100$ & - & $>100$ & $>100$ & $>100$ \\
\hline Acyclovir & $2.3 \pm 0.2$ & $131 \pm 27$ & $>440$ & $>440$ & - & - & - \\
\hline Ganciclovir & - & - & - & - & 7.5 & 5.2 & $\geq 350$ \\
\hline Cidofovir & - & - & - & - & 0.8 & 0.8 & $>300$ \\
\hline
\end{tabular}

[a] Effective concentration required to inhibit virus-induced cytopathicity by $50 \%$. [b] Minimum cytotoxic concentration or compound concentration required to result in a microscopically visible alteration of cell morphology. [c] Cytotoxic concentration required to decrease cell growth by $50 \%$. 
ondary amine moiety. Moreover, compound 1c (the IDA-POM ester of BVDU phosphoramidate) retained moderate antiviral activity against the $\mathrm{TK}^{-} \mathrm{VZV}$ strain, whereas the parent compound BVDU (1) showed no activity at all. This result indicates that some degree of kinase bypass may be achieved and that, to some extent, BVDU-monophosphate is being delivered intracellularly or the phosphoramidic acid formed might have been recognized as a direct substrate by the viral enzyme to exert some antiviral activity. However, the apparent cytostatic activity being tenfold higher for compound $1 \mathrm{c}$ than for BVDU could also be related to the observed (marginal) antiviral activity of $1 \mathrm{c}$ against the VZV TK${ }^{-}$strain.

From Tables 1 and 2, it is evident that compound $1 \mathrm{c}$ (the IDA-POM ester of BVDU phosphoramidate) has significant antiviral activity against $\mathrm{TK}^{+}$HSV-1 and VZV, whereas compound $\mathbf{1} \mathbf{b}$ (the IDA-Me ester of BVDU phosphoramidate) is completely inactive. This result suggests that, between the methyl and POM esters of iminodiacetic acid, the POM ester has a much greater potency than the methyl ester, probably due to its higher lipophilicity assisting permeation through the lipid-rich cell membrane. This suggests that the POM ester might be a potential protecting group to consider for the future design of phosphoramidate prodrugs. Although there are some concerns for toxicity, due to liberation of formaldehyde and pivalic acid (which interrupts carnitine homeostasis in humans) during POM-derived-prodrug metabolism, it is suggested that normal formaldehyde input from the diet and the environment exceeds the exposure from formaldehyde-releasing prodrugs, and simultaneous carnitine supplementation may be administered with pivalate-generating prodrugs in case of long-term treatment. ${ }^{[18,32]}$

The antiviral activities of deazaadenine nucleoside derivatives have been reviewed by Cristalli and co-workers, ${ }^{[33]}$ and some of these compounds showed antiviral activity. For example, 7-deaza-2'-methyladenosine and its derivatives were reported as highly potent agents against the hepatitis $C$ virus. ${ }^{[33,34]}$ We were therefore interested to evaluate the antiviral activity of some deazaadenine nucleosides and the corresponding L-alanine methyl and IDA-POM containing phosphoramidate derivatives. Among all of the deazaadenine nucleosides and phosphoramidate derivatives evaluated, only the 7deaza-nucleoside $5\left(E_{50}: 2.4 \mu \mathrm{M}\right)$ showed significant activity against the VZV $\mathrm{TK}^{+}$strain, although its potency against the $\mathrm{TK}^{-}$VZV strain was eightfold lower. The triester phosphoramidate analogues $\mathbf{5} \mathbf{a}$ and $\mathbf{5 b}\left(\mathrm{EC}_{50}: 37-68 \mu \mathrm{M}\right.$ ) exhibited very weak anti-VZV activity; the activities are nearly 15 - to 28 -fold lower than the corresponding nucleoside $\mathbf{5}$.

The antiviral activities of some phosphoramidate diesters bearing L-aspartyl methyl esters ( $\mathbf{2 d}, \mathbf{4 a}$, and $\mathbf{5 c}$ ) were also evaluated, but none of these compounds showed antiviral activity against any of the tested viruses. No antiviral activity was observed against HSV-2, vaccinia virus (VV), or human cytomegalovirus (HCMV) for any of the compounds in this study.

\section{Stability in human serum}

In order to investigate the stability of these phosphoramidate analogues in biological conditions, the stabilities of two representative ProTides, $\mathbf{1} \mathbf{a}$ and $\mathbf{1} \mathbf{b}$, were investigated at $37^{\circ} \mathrm{C}$ in the presence of human serum by using ${ }^{31} \mathrm{P}$ NMR spectroscopy. The ProTide was dissolved in a mixture of $\left[D_{6}\right] D M S O$ and $D_{2} O$, and then human serum was added. The reaction was monitored over a period of $14 \mathrm{~h}$, as depicted in Figure 3.

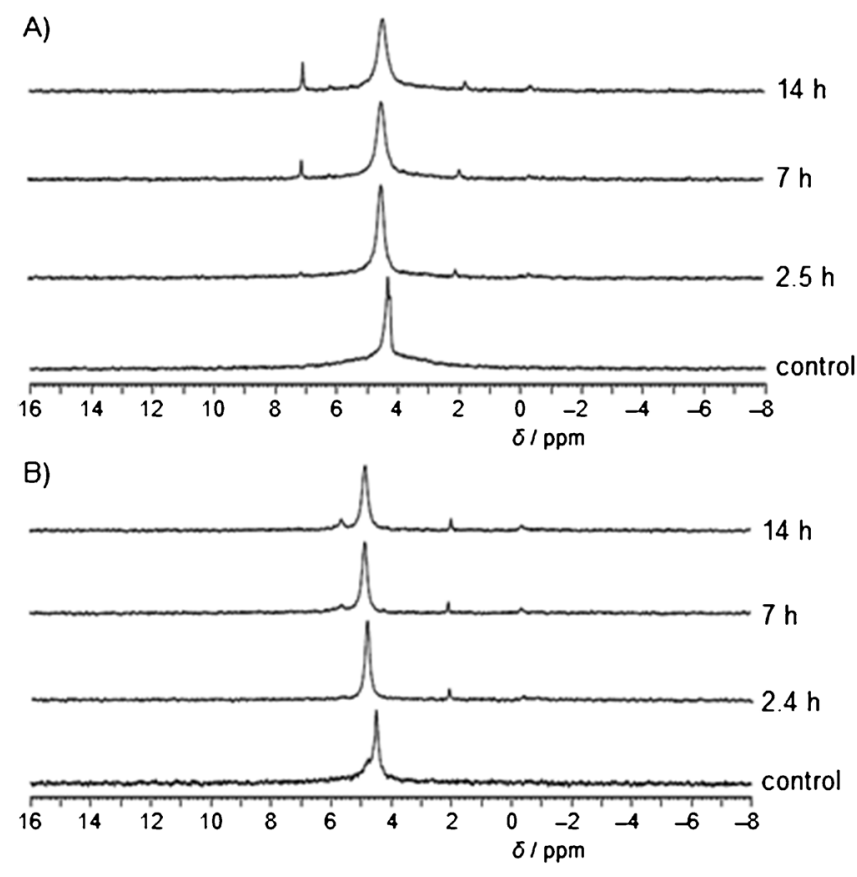

Figure 3. Stack plot of ${ }^{31} \mathrm{P}$ NMR spectra illustrating the stability of ProTides A) $\mathbf{1} \mathbf{a}$ and B) $\mathbf{1} \mathbf{b}$ in human serum at various time intervals; control: no serum added.

The spectra show that both of the ProTides were reasonably stable under these conditions. In fact, more than $90 \%$ of the parent compound was still present after $14 \mathrm{~h}$ of incubation at $37^{\circ} \mathrm{C}$. Compound 1 a was partly hydrolyzed into the proposed metabolite 15 (Figure 4) because a single peak appeared at $\delta=7.07 \mathrm{ppm}$ (Figure $3 \mathrm{~A}$ ). For compound $\mathbf{1} \mathbf{b}$, a peak appeared at $\delta=5.61 \mathrm{ppm}$ (Figure $3 \mathrm{~B}$ ), which might correspond to the metabolite 16 (Figure 4). The proposed metabolites were not characterized further, and the prediction is based on previously published literature, which reported similar ${ }^{31} \mathrm{P}$ chemical shifts

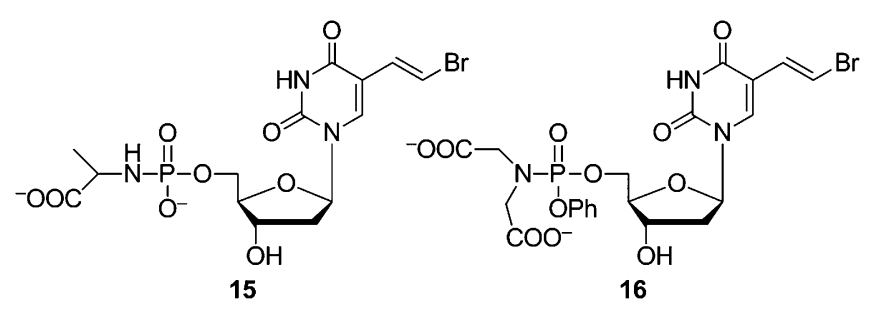

Figure 4. Tentative proposals for the metabolites formed during the serum stability studies with ProTides $\mathbf{1}$ a and $\mathbf{1} \mathbf{b}$. 
that were proved to be characteristic ${ }^{31} \mathrm{P}$ peaks due to the formation of similar metabolites for this type of molecule in human serum. ${ }^{[3]}$ The two small peaks at $\delta \approx 1.77$ and $-0.32 \mathrm{ppm}$ are derived from human serum, as confirmed with blank serum. Therefore, from the data, it could be suggested that this type of phosphoramidate derivative could be reasonably stable in the extracellular medium to allow intact uptake by the target cells.

\section{Conclusions}

A series of phosphoramidate ProTide analogues of BVDU and of deazaadenine nucleosides were synthesized and investigated for their antiviral activity and cytotoxicity against DNA viruses. The BVDU aryloxy phosphoramidates of L-alanine methyl ester and pivaloyloxymethyl iminodiacetate ester showed significant activity against HSV-1 and VZV, although relatively less activity than the corresponding parent drug BVDU. The amino acid L-alanine methyl ester and secondary amine IDA-POM ester were found to be equally potent against varicella-zoster virus. Some success was achieved in delivering the nucleoside monophosphate intracellularly for phosphoramidate compounds bearing the IDA-POM moiety (for example, 1 c) against VZV to bypass the thymidine kinase pathway, which indicates the POM moiety is a potential carboxyl protecting group in the design of prodrugs. The application of the phosphoramidate ProTide technology was only partly successful because none of these compounds showed a significant increase in antiviral activity against the TK-deficient virus strains.

\section{Experimental Section}

General: NMR spectra were recorded on a Bruker Avance II $300 \mathrm{MHz}$ spectrometer with $5 \mathrm{~mm}$ broad band probe and on a $500 \mathrm{MHz}$ spectrometer, which is equipped with a TXI-HCP Z gradient probe. The spectra were processed with Bruker Topspin 2.1 software. Chemical shifts $(\delta)$ were expressed in parts per million (ppm). The ${ }^{1} \mathrm{H}$ and ${ }^{13} \mathrm{C}$ NMR chemical shifts were referenced relative to a tetramethylsilane peak $(\delta=0.00 \mathrm{ppm})$. All signals in the proton and carbon 1D NMR spectra were assigned by using 2D COSY, ${ }^{1} \mathrm{H}-{ }^{13} \mathrm{C}$ (natural abundance) HSQC, and ${ }^{1} \mathrm{H}-{ }^{13} \mathrm{C}$ HMBC NMR spectra. Mass spectra were acquired on a quadrupole orthogonal acceleration time-of-flight mass spectrometer (Synapt G2 HDMS, Waters, Milford, MA, USA). Samples were infused at $3 \mu \mathrm{L} \mathrm{min}^{-1}$, and spectra were obtained in positive (or negative) ionization mode with a resolution of 15000 (FWHM) by using leucine enkephalin as a lock mass. Chemicals of analytical and synthetic grade were obtained from commercial sources and were used as received. Flash silica column chromatography was performed on $60 \mathrm{~A}, 0.035$ $0.070 \mathrm{~mm}$ silica gel (Acros Organics). Human serum was purchased from Sigma Aldrich.

Pivaloyloxymethyl iodide (11): Sodium iodide $(45 \mathrm{~g}, 0.3 \mathrm{~mol})$ was added to a solution of pivaloyloxymethyl chloride $(10 ; 25 \mathrm{~g}$, $0.17 \mathrm{~mol}$ ) in acetonitrile $(50 \mathrm{~mL})$ and the suspension was allowed to stir at $30^{\circ} \mathrm{C}$ overnight under an argon atmosphere. A mixture of $\mathrm{CH}_{2} \mathrm{Cl}_{2}(250 \mathrm{~mL})$ and water $(250 \mathrm{~mL})$ was added. The mixture was allowed to stir for $10 \mathrm{~min}$, then separated into two layers. The aqueous layer was discarded and the organic layer was washed with sodium thiosulfate $(2 \%)$. The organic layer was dried over an- hydrous magnesium sulfate and concentrated under vacuum to give iodomethyl pivalate (11) as a yellow liquid (85\%): ${ }^{1} \mathrm{H}$ NMR $\left(300 \mathrm{MHz}, \mathrm{CDCl}_{3}\right): \delta=5.89\left(\mathrm{~s}, 2 \mathrm{H}, \mathrm{CH}_{2}\right), 1.16 \mathrm{ppm}\left(\mathrm{s}, 9 \mathrm{H}, \mathrm{C}\left(\mathrm{CH}_{3}\right)_{3}\right)$; ${ }^{13} \mathrm{C} \mathrm{NMR}\left(75 \mathrm{MHz}, \mathrm{CDCl}_{3}\right): \delta=176.5,39.1,31.7,26.8 \mathrm{ppm}$.

N-Benzyloxycarbonyl iminodiacetic acid (7): Benzyl chloroformate $(18 \mathrm{~mL}, 0.13 \mathrm{~mol})$ was added dropwise to a solution of iminodiacetic acid, $6(15 \mathrm{~g}, 0.1 \mathrm{~mol})$ in $\mathrm{NaOH}(2 \mathrm{M}, 600 \mathrm{~mL})$ at $0^{\circ} \mathrm{C}$. The mixture was allowed to stir at room temperature for $4 \mathrm{~h}$. The mixture was then acidified to $\mathrm{pH} 2$ with $\mathrm{HCl}(2 \mathrm{M})$ and extracted three times with diethyl ether. The combined diethyl ether layers were dried over anhydrous $\mathrm{MgSO}_{4}$, and the solvent was evaporated under reduced pressure to obtain the crude product as an oil. The crude product was then purified on a silica gel column eluted with ethyl acetate/hexane (6:4) to obtain the pure product (7) as a colorless oil (70\%): ${ }^{1} \mathrm{H} \mathrm{NMR}\left(300 \mathrm{MHz}, \mathrm{CDCl}_{3}\right): \delta=9.88$ (brs, $\left.2 \mathrm{H}, \mathrm{OH}\right), 7.31-$ $7.28(\mathrm{~m}, 1 \mathrm{H}$, aromatic $\mathrm{H}), 5.15\left(\mathrm{~s}, 2 \mathrm{H}, \mathrm{CH}_{2}\right), 4.18\left(\mathrm{~s}, 2 \mathrm{H}, \mathrm{CH}_{2}\right)$, $4.13 \mathrm{ppm}\left(\mathrm{s}, 2 \mathrm{H}, \mathrm{CH}_{2}\right) ;{ }^{13} \mathrm{C} \mathrm{NMR}\left(75 \mathrm{MHz}, \mathrm{CDCl}_{3}\right): \delta=174.6,173.9$, 156.4, 135.9, 128.9, 128.7, 128.2, 68.8, 50.2, 50.1 ppm; HRMS (ESI-): calcd for $\mathrm{C}_{12} \mathrm{H}_{12} \mathrm{NO}_{6}[M-\mathrm{H}]^{-}:$266.0670; found: 266.0674 .

Bis(pivaloyloxymethyl)- $\mathrm{N}$-benzyloxycarbonyl iminodiacetate (8): Silver carbonate $(32.5 \mathrm{~g}, 118 \mathrm{mmol})$ and pivaloyloxymethyl iodide $(11 ; 35.4 \mathrm{~mL}, 0.24 \mathrm{~mol})$ were added to a solution of $7(6.3 \mathrm{~g}$, $23.6 \mathrm{mmol}$ ) in dry $\mathrm{N}, \mathrm{N}$-dimethylformamide (DMF; $120 \mathrm{~mL}$ ). The color of the reaction mixture changed from greenish to brown in $15 \mathrm{~min}$ and was allowed to stir at room temperature overnight. The solid particles were removed by filtration and washed with EtOAc. The filtrate was concentrated under reduced pressure and purified by flash column chromatography eluted with EtOAc/ hexane (1:9 to $2: 8)$ to obtain 8 as a colorless oil $(87 \%): R_{\mathrm{f}}=0.2$ (EtOAc/hexane, 1:9); ${ }^{1} \mathrm{H}$ NMR $\left(300 \mathrm{MHz}, \mathrm{CDCl}_{3}\right): \delta=7.34(\mathrm{~m}, 5 \mathrm{H}$, aromatic H), $5.79\left(\mathrm{~s}, 2 \mathrm{H}, \mathrm{CH}_{2}\right), 5.73\left(\mathrm{~s}, 2 \mathrm{H}, \mathrm{CH}_{2}\right), 5.14\left(\mathrm{~s}, 2 \mathrm{H}, \mathrm{CH}_{2}\right), 4.21$ $\left(\mathrm{s}, 2 \mathrm{H}, \mathrm{CH}_{2}\right), 4.15\left(\mathrm{~s}, 2 \mathrm{H}, \mathrm{CH}_{2}\right), 1.21\left(\mathrm{~s}, 9 \mathrm{H}, \mathrm{C}\left(\mathrm{CH}_{3}\right)_{3}\right), 1.17 \mathrm{ppm}(\mathrm{s}, 9 \mathrm{H}$, $\left.\mathrm{C}\left(\mathrm{CH}_{3}\right)_{3}\right) ;{ }^{13} \mathrm{C}$ NMR $\left(75 \mathrm{MHz}, \mathrm{CDCl}_{3}\right): \delta=177.15,177.07,168.4,168.3$, 155.9, 136.0, 128.7, 128.4, 127.9, 80.1, 80.0, 68.3, 49.3, 49.1, 38.9, 38.8, 27.0, 26.9 ppm; HRMS (ESI+): calcd for $\mathrm{C}_{24} \mathrm{H}_{34} \mathrm{NO}_{10}[\mathrm{M}+\mathrm{H}]^{+}$: 496.2177; found: 496.2171 .

Bis(pivaloyloxymethyl)iminodiacetate hydrochloride salt (9): $10 \% \mathrm{Pd} / \mathrm{C}(2 \mathrm{~g}, 8.3 \mathrm{mmol})$ was added to a solution of $8(10.2 \mathrm{~g}$, $20.6 \mathrm{mmol})$ in methanol $(500 \mathrm{~mL}) . \mathrm{HCl}(5 \mathrm{~N}$ in isopropanol, $4 \mathrm{~mL})$ was added to the resulting mixture, which was then stirred under $\mathrm{H}_{2}$ at room temperature for $4 \mathrm{~h}$. The catalyst was filtered over Celite and washed with methanol. The filtrate was evaporated to dryness and triturated with diethyl ether to obtain pure compound 9 as a white solid (98\%): $R_{\mathrm{f}}=0.14$ (EtOAc/hexane, 3:7); ${ }^{1} \mathrm{H}$ NMR $\left(300 \mathrm{MHz}, \mathrm{CDCl}_{3}\right): \delta=5.86\left(\mathrm{~s}, 4 \mathrm{H}, \mathrm{CH}_{2}\right), 4.16\left(\mathrm{~s}, 4 \mathrm{H}, \mathrm{CH}_{2}\right), 1.22 \mathrm{ppm}$ $\left(\mathrm{s}, 18 \mathrm{H}, \mathrm{C}\left(\mathrm{CH}_{3}\right)_{3}\right) ;{ }^{13} \mathrm{C}$ NMR $\left(75 \mathrm{MHz}, \mathrm{CDCl}_{3}\right): \delta=177.2,167.8,80.4$, 48.2, 39.0, $27.1 \mathrm{ppm}$; HRMS (ESI+): calcd for $\mathrm{C}_{16} \mathrm{H}_{28} \mathrm{NO}_{8}[\mathrm{M}+\mathrm{H}]^{+}$: 362.1809; found: 362.1808 .

General procedure for synthesis of phosphoramidates: Step 1: A solution/suspension of the appropriate amine/amino acid ester hydrochloride salt (3.5 equiv) in anhydrous $\mathrm{CH}_{2} \mathrm{Cl}_{2}$ was prepared and cooled to $-15^{\circ} \mathrm{C}$. Dichlorophenylphosphate ( 2.5 equiv) was added slowly. After $10 \mathrm{~min}$, a solution of $\mathrm{N}$-methylimidazole (10 equiv) in dry $\mathrm{CH}_{2} \mathrm{Cl}_{2}$ was added dropwise. The mixture was left to stir for $1 \mathrm{~h}$. (In the cases of secondary amines, the mixtures were allowed to reach room temperature slowly and left for 10-12 h.) Step 2: In a separate flask, a suspension of the appropriate nucleoside (1 equiv) in anhydrous $\mathrm{CH}_{2} \mathrm{Cl}_{2}$ was cooled to $-5^{\circ} \mathrm{C}$. With stirring, the solution prepared above was added slowly over a period of $1 \mathrm{~h}$, with the temperature kept near $-5^{\circ} \mathrm{C}$. The cooling bath was removed, and the reaction was left to stir at room temperature 
until TLC indicated a reasonable amount of product formation. The reaction mixture was then evaporated to dryness under reduced pressure, and the residue was purified by column chromatography eluted with $\mathrm{CH}_{2} \mathrm{Cl}_{2} / \mathrm{MeOH}$ in different proportions (generally, 2-5\% methanol in $\mathrm{CH}_{2} \mathrm{Cl}_{2}$ ). The yields of the reactions were in the range of $25-70 \%$. The product structures were confirmed by NMR spectroscopy and HRMS, as described below. ${ }^{1} \mathrm{H},{ }^{13} \mathrm{C}$ and ${ }^{31} \mathrm{P}$ NMR spectra are provided in the Supporting Information.

Brivudin-5'-[phenyl(methoxy-L-alaninyl)]phosphate (1 a): Yield: $60 \% ; R_{\mathrm{f}}=0.47\left(\mathrm{CH}_{2} \mathrm{Cl}_{2} / \mathrm{MeOH}\right.$, 9.5:0.5); ${ }^{1} \mathrm{H}$ NMR $\left(500 \mathrm{MHz}, \mathrm{CDCl}_{3}\right)$ : $\delta=7.63,7.60(2 \mathrm{~s}, 1 \mathrm{H}, \mathrm{H} 6), 7.41,7.38(2 \mathrm{~d}, 1 \mathrm{H}, J=13.7 \mathrm{~Hz}, \mathrm{CH}=$ $\mathrm{CHBr}), 7.33-7.14(\mathrm{~m}, 5 \mathrm{H}, \mathrm{OPh}), 6.71,6.67(2 \mathrm{~d}, 1 \mathrm{H}, J=13.7 \mathrm{~Hz}, \mathrm{CH}=$ $\mathrm{CHBr}$ ), 6.27, 6.22 (two sets of apparent $\mathrm{t}, 1 \mathrm{H}, J_{1^{\prime}, 2^{\prime} \mathrm{a}}=J_{1^{\prime}, 2^{\prime} \mathrm{b}}=6.3 \mathrm{~Hz}$, $\left.\mathrm{H} 1^{\prime}\right), 4.52,4.47\left(2 \mathrm{~m}, 1 \mathrm{H}, \mathrm{H} 3^{\prime}\right), 4.43-4.19\left(\mathrm{~m}, 3 \mathrm{H}, \mathrm{H}^{\prime}, \mathrm{H} 5^{\prime \prime}, \mathrm{NH}\right)$, 4.17$4.09\left(\mathrm{~m}, 1 \mathrm{H}, \mathrm{H} 4^{\prime}\right), 4.06-3.95(\mathrm{~m}, 1 \mathrm{H}, \mathrm{H}-\alpha-a l a), 3.70,3.69(2 \mathrm{~s}, 3 \mathrm{H}$, $\left.\mathrm{OCH}_{3}\right), 2.44-2.38\left(\mathrm{~m}, 1 \mathrm{H}, \mathrm{H} 2^{\prime} \mathrm{a}\right), 2.06-2.02\left(\mathrm{~m}, 1 \mathrm{H}, \mathrm{H} 2^{\prime} \mathrm{b}\right), 1.37$, 1.35 ppm (d, $3 \mathrm{H}, \mathrm{CH}_{3}$-ala); ${ }^{13} \mathrm{C} \mathrm{NMR}\left(125 \mathrm{MHz}, \mathrm{CDCl}_{3}\right): \delta=174.3$, 174.2 (CO-ala), 161.9, 161.8 (C4), 150.4, 150.3 (phenyl C), 149.6 (C2), 137.8, 137.7 (C6), 130.0 (phenyl C), $128.7(\mathrm{CH}=\mathrm{CHBr}), 125.5$ (phenyl C), 120.3-120.2 (phenyl C), 111.7, $111.6(\mathrm{C} 5), 110.0(\mathrm{CH}=\mathrm{CHBr}), 85.8$, $85.4\left(\mathrm{C}^{\prime}\right), 85.3\left(\mathrm{C} 4^{\prime}\right), 70.9,70.5\left(\mathrm{C} 3^{\prime}\right), 66.2,65.9\left(\mathrm{C}^{\prime}\right), 52.9,52.8$ $\left(\mathrm{OCH}_{3}\right), 50.5,50.4$ (C- $\alpha$-ala), 40.6, $40.4\left(\mathrm{C2}^{\prime}\right), 20.9,20.8 \mathrm{ppm}\left(\mathrm{CH}_{3}-\right.$ ala); ${ }^{31} \mathrm{P}$ NMR (202 MHz, $\left.\mathrm{CDCl}_{3}\right): \delta=3.47,3.17 \mathrm{ppm}$; HRMS (ESI+): calcd for $\mathrm{C}_{21} \mathrm{H}_{26} \mathrm{BrN}_{3} \mathrm{O}_{9} \mathrm{P}[\mathrm{M}+\mathrm{H}]^{+}: 574.0585$; found: 574.0579 .

Brivudin-5'-[phenylbis(methoxyiminodiacetyl)]phosphate (1 b): Yield: $60 \% ; R_{\mathrm{f}}=0.46\left(\mathrm{CH}_{2} \mathrm{Cl}_{2} / \mathrm{MeOH}, 9.5: 0.5\right) ;{ }^{1} \mathrm{H} \mathrm{NMR}(500 \mathrm{MHz}$, $\left.\mathrm{CDCl}_{3}\right): \delta=7.65,7.59(2 \mathrm{~s}, 1 \mathrm{H}, \mathrm{H6}), 7.41,7.39(2 \mathrm{~d}, 1 \mathrm{H}, J=13.6 \mathrm{~Hz}$, $\mathrm{CH}=\mathrm{CHBr}), 7.32-7.13(\mathrm{~m}, 5 \mathrm{H}, \mathrm{OPh}), 6.72,6.67(2 \mathrm{~d}, 1 \mathrm{H}, J=13.6 \mathrm{~Hz}$, $\mathrm{CH}=\mathrm{CHBr}$ ) , 6.28, 6.25 (two sets of apparent $\mathrm{t}, 1 \mathrm{H}, J_{1^{\prime}, 2^{\prime} \mathrm{a}}=J_{1^{\prime}, 2^{\prime} \mathrm{b}}=$ $\left.6.5 \mathrm{~Hz}, \mathrm{H} 1^{\prime}\right), 4.51-4.48\left(\mathrm{~m}, 1 \mathrm{H}, \mathrm{H} 3^{\prime}\right), 4.43-4.42\left(\mathrm{~m}, 2 \mathrm{H}, \mathrm{H} 5^{\prime}, \mathrm{H}^{\prime \prime}\right)$, 4.11-3.87 (m, 5H, H4', $\left.\mathrm{CH}_{2}-\mathrm{IDA}\right), 3.66,3.65\left(2 \mathrm{~s}, 6 \mathrm{H}, \mathrm{OCH}_{3}\right), 2.45-$ $2.36\left(\mathrm{~m}, 1 \mathrm{H}, \mathrm{H} 2^{\prime} \mathrm{a}\right), \quad 2.07-2.01 \mathrm{ppm}\left(\mathrm{m}, 1 \mathrm{H}, \mathrm{H} 2^{\prime} \mathrm{b}\right) ;{ }^{13} \mathrm{C} \mathrm{NMR}$ $\left(125 \mathrm{MHz}, \mathrm{CDCl}_{3}\right): \delta=170.6,170.4$ (CO-IDA), 162.0, 161.9 (C4), $150.6,150.5,150.4$ (phenyl C), 149.7 (C2), 138.0, 137.9 (C6), 130.3130.09 (phenyl C), 128.9, $128.8(\mathrm{CH}=\mathrm{CHBr}), 125.7$ (phenyl $\mathrm{C}$ ), 120.4120.3 (phenyl C), 111.8, 111.7 (C5), 110.2, 110.1 ( $\mathrm{CH}=\mathrm{CHBr}), 85.5$, 85.4, 85.3, 85.2 (C1' and $\left.\mathrm{C}^{\prime}\right), 70.7,70.6\left(\mathrm{C}^{\prime}\right), 66.5,66.4\left(\mathrm{C}^{\prime}\right), 52.7$, $52.6\left(\mathrm{OCH}_{3}\right), \quad 48.4 \quad\left(\mathrm{CH}_{2}-\mathrm{IDA}\right), \quad 40.7, \quad 40.6 \mathrm{ppm} \quad\left(\mathrm{C2}^{\prime}\right) ;{ }^{31} \mathrm{P} \mathrm{NMR}$ $\left(202 \mathrm{MHz}, \mathrm{CDCl}_{3}\right): \delta=4.81,4.78 \mathrm{ppm}$; HRMS $(\mathrm{ESI}+)$ ): calcd for $\mathrm{C}_{23} \mathrm{H}_{28} \mathrm{BrN}_{3} \mathrm{O}_{11} \mathrm{P}[M+\mathrm{H}]^{+}$: 632.0640; found: 632.0646 .

Brivudin-5'-[phenylbis(pivaloyloxymethyliminodiacetyl)] phosphate (1 c): Yield: $40 \% ; R_{\mathrm{f}}=0.55\left(\mathrm{CH}_{2} \mathrm{Cl}_{2} / \mathrm{MeOH}, 9.5: 0.5\right) ;{ }^{1} \mathrm{H} \mathrm{NMR}$ $\left(500 \mathrm{MHz}, \mathrm{CDCl}_{3}\right): \delta=9.51(\mathrm{~s}, 1 \mathrm{H}, \mathrm{NH}), 7.60,7.58(2 \mathrm{~s}, 1 \mathrm{H}, \mathrm{H} 6), 7.42$, $7.39(2 \mathrm{~d}, 1 \mathrm{H}, J=13.6 \mathrm{~Hz}, \mathrm{CH}=\mathrm{CHBr}), 7.34-7.16(\mathrm{~m}, 5 \mathrm{H}, \mathrm{OPh}), 6.70$, $6.68(2 \mathrm{~d}, 1 \mathrm{H}, J=13.6 \mathrm{~Hz}, \mathrm{CH}=\mathrm{CHBr}), 6.26,6.23$ (two sets of apparent $\left.\mathrm{t}, 1 \mathrm{H}, J_{1^{\prime}, 2^{\prime} \mathrm{a}}=J_{1^{\prime}, 2^{\prime} \mathrm{b}}=6.3 \mathrm{~Hz}, \mathrm{H} 1^{\prime}\right), 5.78-5.70\left(\mathrm{~m}, 4 \mathrm{H}, \mathrm{CH}_{2}-\mathrm{POM}\right)$, 4.50-4.40 (m, 3H, H3', H5', H5 '), 4.16-3.94 (m, 5H, H4', $\left.\mathrm{CH}_{2}-\mathrm{IDA}\right)$, 2.46-2.38 (m, $\left.1 \mathrm{H}, \mathrm{H} 2^{\prime} \mathrm{a}\right), 2.08-2.01\left(\mathrm{~m}, 1 \mathrm{H}, \mathrm{H} 2^{\prime} \mathrm{b}\right), 1.20,1.19 \mathrm{ppm}$ $(2 \mathrm{~s}, 18 \mathrm{H}, t \mathrm{Bu}-\mathrm{POM}) ;{ }^{13} \mathrm{C}$ NMR $\left(125 \mathrm{MHz}, \mathrm{CDCl}_{3}\right): \delta=177.4(2 \mathrm{CO}-$ POM), 168.9, 168.8 (CO-IDA), 161.7 (C4), 150.4, 150.3 (3 phenyl C), 149.5 (C2), 137.9, 137.8 (C6),130.2 (phenyl C), 128.8, $128.7(\mathrm{CH}=$ CHBr), 125.9 (phenyl C), 120.4-120.3 (4 phenyl C), 111.8, 111.7 (C5), $110.3,110.2(\mathrm{CH}=\mathrm{CHBr}), 85.5\left(\mathrm{C}^{\prime}\right), 85.2,85.1\left(\mathrm{C}^{\prime}\right), 80.4\left(\mathrm{CH}_{2}-\mathrm{POM}\right)$, 70.9, $70.4\left(\mathrm{C}^{\prime}\right), 66.4,66.3\left(\mathrm{C} 5^{\prime}\right), 48.4,48.3\left(\mathrm{CH}_{2}-\mathrm{IDA}\right), 40.7,40.5\left(\mathrm{C2} 2^{\prime}\right)$, 39.1 (tBu quaternary C), $27.1 \mathrm{ppm}(t \mathrm{Bu}) ;{ }^{31} \mathrm{P} \mathrm{NMR}\left(202 \mathrm{MHz}, \mathrm{CDCl}_{3}\right)$ : $\delta=4.55,4.53$ ppm; HRMS (ESI +): calcd for $\mathrm{C}_{33} \mathrm{H}_{44} \mathrm{BrN}_{3} \mathrm{O}_{15} \mathrm{P}[\mathrm{M}+\mathrm{H}]^{+}$ : 832.1688; found: 832.1680 .

\section{2'-Deoxy-1-deazaadenosine-5'-[phenyl(methoxy-L-alaninyl)]} phosphate (2a): Yield: 65\%; $R_{\mathrm{f}}=0.36\left(\mathrm{CH}_{2} \mathrm{Cl}_{2} / \mathrm{MeOH}, 9.0: 1.0\right)$; ${ }^{1} \mathrm{H}$ NMR $\left(500 \mathrm{MHz}, \mathrm{CDCl}_{3}\right): \delta=8.17,8.13(2 \mathrm{~s}, 1 \mathrm{H}, \mathrm{H} 8), 8.04(\mathrm{~d}, 1 \mathrm{H}$, $J_{2,1}=5.4 \mathrm{~Hz}, \mathrm{H} 2$ ), 7.38-7.16 (m, 5H, OPh), 6.64, 6.61 (two sets of ap- parent t, $\left.1 \mathrm{H}, J_{1^{\prime}, 2^{\prime} \mathrm{a}}=J_{1^{\prime}, 2^{\prime} \mathrm{b}}=6.5 \mathrm{~Hz}, \mathrm{H1} 1^{\prime}\right), 6.48\left(\mathrm{~d}, 1 \mathrm{H}, J_{1,2}=5.4 \mathrm{~Hz}, \mathrm{H1}\right)$, $5.34\left(\mathrm{~s}, 2 \mathrm{H}, \mathrm{NH}_{2}\right), 4.75-4.51\left(\mathrm{~m}, 2 \mathrm{H}, \mathrm{H3}^{\prime}, \mathrm{NH}\right), 4.44-4.43\left(\mathrm{~m}, 2 \mathrm{H}, \mathrm{H} 5^{\prime}\right.$, $\left.\mathrm{H} 5^{\prime \prime}\right), 4.31-4.30\left(\mathrm{~m}, 1 \mathrm{H}, \mathrm{H} 4^{\prime}\right), 4.08-4.02(\mathrm{~m}, 1 \mathrm{H}, \mathrm{H}-\alpha$-ala $), 3.72,3.70$ $\left(2 \mathrm{~s}, 3 \mathrm{H}, \mathrm{OCH}_{3}\right), 2.81-2.53\left(\mathrm{~m}, 2 \mathrm{H}, \mathrm{H} 2^{\prime} \mathrm{a}, \mathrm{H}^{\prime} \mathrm{b}\right), 1.39,1.35 \mathrm{ppm}(\mathrm{d}$, $3 \mathrm{H}, \mathrm{CH}_{3}$-ala); ${ }^{13} \mathrm{C}$ NMR $\left(125 \mathrm{MHz}, \mathrm{CDCl}_{3}\right): \delta=173.7,173.6$ (CO-ala), 150.3, 150.2 (phenyl C), 146.5 (C4), 145.6 (C6), 145.1 (C2), 138.3, 138.1 (C8), 129.3 (phenyl C), 124.6 (phenyl C), 123.4 (C5), 119.8 (2 phenyl C), 103.0 (C1), 84.7, 85.6 (C4'), 83.6, 83.5 (C1'), 70.6 (C3'), 66.2, $65.9\left(\mathrm{C}^{\prime}\right), 52.1\left(\mathrm{OCH}_{3}\right), 49.9(\mathrm{C}-\alpha-a \mathrm{ala}), 39.7\left(\mathrm{C}^{\prime}\right), 20.2$, $20.1 \mathrm{ppm}\left(\mathrm{CH}_{3}\right.$-ala); ${ }^{31} \mathrm{P}$ NMR $\left(202 \mathrm{MHz}, \mathrm{CDCl}_{3}\right): \delta=3.10,2.90 \mathrm{ppm}$; HRMS (ESI+): calcd for $\mathrm{C}_{21} \mathrm{H}_{27} \mathrm{~N}_{5} \mathrm{O}_{7} \mathrm{P}[\mathrm{M}+\mathrm{H}]^{+}$: 492.1642; found: 492.1651.

2'-Deoxy-1-deazaadenosine-5'-[phenylbis(methoxyiminodiacetyl)] phosphate (2b): Yield: $62 \% ; R_{\mathrm{f}}=0.55\left(\mathrm{CH}_{2} \mathrm{Cl}_{2} / \mathrm{MeOH}, 9.0: 1.0\right)$; ${ }^{1} \mathrm{H}$ NMR $\left(300 \mathrm{MHz}, \mathrm{CDCl}_{3}\right): \delta=8.15,8.00(2 \mathrm{~s}, 1 \mathrm{H}, \mathrm{H} 8), 7.97(\mathrm{~d}, 1 \mathrm{H}$, $\left.J_{2,1}=5.5 \mathrm{~Hz}, \mathrm{H} 2\right), 7.28-7.08(\mathrm{~m}, 5 \mathrm{H}, \mathrm{OPh}), 6.54$ (apparent $\mathrm{t}, 1 \mathrm{H}$, $\left.J_{1^{\prime}, z^{\prime} \mathrm{a}}=J_{1^{\prime}, 2^{\prime} \mathrm{b}}=6.6 \mathrm{~Hz}, \mathrm{H} 1^{\prime}\right), 6.41\left(\mathrm{~d}, 1 \mathrm{H}, J_{1,2}=5.5 \mathrm{~Hz}, \mathrm{H} 1\right), 5.15(\mathrm{~s}, 2 \mathrm{H}$, $\left.\mathrm{NH}_{2}\right), 4.75-4.55\left(\mathrm{~m}, 1 \mathrm{H}, \mathrm{H} 3^{\prime}\right), 4.44-4.32\left(\mathrm{~m}, 2 \mathrm{H}, \mathrm{H} 5^{\prime}, \mathrm{H}^{\prime \prime}\right), 4.26-4.13$ $\left(\mathrm{m}, 1 \mathrm{H}, \mathrm{H} 4^{\prime}\right), 4.09-3.86\left(\mathrm{~m}, 4 \mathrm{H}, \mathrm{CH}_{2}-\mathrm{IDA}\right), 3.63,3.61\left(2 \mathrm{~s}, 3 \mathrm{H}, \mathrm{OCH}_{3}\right)$, 2.78-2.38 ppm (m, $\left.2 \mathrm{H}, \mathrm{H2}{ }^{\prime} \mathrm{a}, \mathrm{H} 2^{\prime} \mathrm{b}\right) ;{ }^{13} \mathrm{C}$ NMR $\left(75 \mathrm{MHz}, \mathrm{CDCl}_{3}\right): \delta=$ 169.9, 169.8 (CO-IDA), 150.3, 150.2 (phenyl C), 146.6 (C4), 145.5 (C6), 145.1 (C2), 138.2, 138.0 (C8), 129.7, 129.4, 128.9 (phenyl C), 124.8 (phenyl C), 123.5 (C5), 119.9, 119.8, 119.7 (phenyl C), 102.9 (C1), 84.6-84.4 (C4'), 83.4, 83.2 (C1'), 70.8, $70.7\left(\mathrm{C}^{\prime}\right), 66.3,65.8\left(\mathrm{C5}^{\prime}\right)$, 51.8, $51.7\left(\mathrm{OCH}_{3}\right), 47.6,47.5\left(\mathrm{CH}_{2}-\mathrm{IDA}\right), 39.7 \mathrm{ppm}\left(\mathrm{C2}^{\prime}\right) ;{ }^{31} \mathrm{P} \mathrm{NMR}$ $\left(202 \mathrm{MHz}, \mathrm{CDCl}_{3}\right): \delta=4.47,4.37 \mathrm{ppm}$; HRMS (ESI+): calcd for $\mathrm{C}_{23} \mathrm{H}_{29} \mathrm{~N}_{5} \mathrm{O}_{9} \mathrm{P}[\mathrm{M}+\mathrm{H}]^{+}:$:550.1697; found: 550.1704.

2'-Deoxy-1-deazaadenosine-5'-[phenylbis(pivaloyloxymethyliminodiacetyl)] phosphate (2c): Yield: $70 \% ; R_{\mathrm{f}}=0.6\left(\mathrm{CH}_{2} \mathrm{Cl}_{2} / \mathrm{MeOH}_{\text {, }}\right.$ 9.0:1.0); ${ }^{1} \mathrm{H}$ NMR $\left(500 \mathrm{MHz}, \mathrm{CDCl}_{3}\right): \delta=8.09\left(\mathrm{~d}, 1 \mathrm{H}, J_{2,1}=5.6 \mathrm{~Hz}, \mathrm{~Hz}\right)$, $8.06(\mathrm{~s}, 1 \mathrm{H}, \mathrm{H} 8), 7.41-7.22(\mathrm{~m}, 5 \mathrm{H}, \mathrm{OPh}), 6.62$ (apparent $\mathrm{t}, 1 \mathrm{H}$, $\left.J_{1^{\prime}, 2^{\prime} \mathrm{a}}=J_{1^{\prime}, 2^{\prime} \mathrm{b}}=6.6 \mathrm{~Hz}, \mathrm{H} 1^{\prime}\right), 6.53\left(\mathrm{~d}, 1 \mathrm{H}, J_{1,2}=5.6 \mathrm{~Hz}, \mathrm{H} 1\right), 5.85-5.81$ $\left.\left(\mathrm{m}, 4 \mathrm{H}, \mathrm{CH}_{2}-\mathrm{POM}\right), 5.14\left(\mathrm{~s}, 2 \mathrm{H}, \mathrm{NH}_{2}\right), 4.75-4.72(\mathrm{~m}, 1 \mathrm{H}, \mathrm{H3})^{\prime}\right), 4.52-$ $4.45\left(\mathrm{~m}, 2 \mathrm{H}, \mathrm{H} 5^{\prime}, \mathrm{H}^{\prime \prime}\right), 4.32-4.26\left(\mathrm{~m}, 1 \mathrm{H}, \mathrm{H} 4^{\prime}\right), 4.19-4.06(\mathrm{~m}, 4 \mathrm{H}$, $\left.\mathrm{CH}_{2}-\mathrm{IDA}\right), 2.91-2.52\left(\mathrm{~m}, 2 \mathrm{H}, \mathrm{H} 2^{\prime} \mathrm{a}, \mathrm{H} 2^{\prime} \mathrm{b}\right), 1.28 \mathrm{ppm} \quad(\mathrm{s}, 18 \mathrm{H}$, $t \mathrm{Bu}) ;{ }^{13} \mathrm{C}$ NMR (125 MHz, CDCl $)$ : $\delta=176.7,176.6$ (CO-POM), 168.3, 168.2 (CO-IDA), 150.1, 150.0 (phenyl C), 146.5 (C4), 145.5 (C6), 145.1 (C2), 138.3, 138.0 (C8), 129.4, 128.9, 124.9 (phenyl C), 123.6 (C5), 119.8 (2 phenyl C), $102.9(\mathrm{C} 1), 84.5,84.3\left(\mathrm{C}^{\prime}\right), 83.4\left(\mathrm{C}^{\prime}\right), 79.6\left(\mathrm{CH}_{2}-\right.$ POM), 70.9, $70.7\left(\mathrm{C}^{\prime}\right), 66.2,65.9\left(\mathrm{C}^{\prime}\right), 47.6,47.5\left(\mathrm{CH}_{2}-\mathrm{IDA}\right), 39.4$, $39.3\left(\mathrm{C}^{\prime}\right), \quad 38.4$ (tBu quaternary $\left.\mathrm{C}\right), 26.4 \mathrm{ppm}(t \mathrm{Bu}) ;{ }^{31} \mathrm{P} \mathrm{NMR}$ $\left(202 \mathrm{MHz}, \mathrm{CDCl}_{3}\right): \delta=4.19,4.07 \mathrm{ppm}$; HRMS (ESI+): calcd for $\mathrm{C}_{33} \mathrm{H}_{45} \mathrm{~N}_{5} \mathrm{O}_{13} \mathrm{P}[M+\mathrm{H}]^{+}$: 750.2746; found: 750.2747 .

2'-Deoxy-6-chloro-3-deazaadenosine-5'-[phenyl(methoxy-L-alaninyl)] phosphate (3a): Yield: $50 \% ; R_{\mathrm{f}}=0.51 \quad\left(\mathrm{CH}_{2} \mathrm{Cl}_{2} / \mathrm{MeOH}\right.$, 9.5:0.5); ${ }^{1} \mathrm{H}$ NMR $\left(500 \mathrm{MHz}, \mathrm{CDCl}_{3}\right): \delta=8.30,8.21(2 \mathrm{~s}, 1 \mathrm{H}, \mathrm{H} 8), 8.15$ $\left(\mathrm{d}, 1 \mathrm{H}, J_{2,3}=5.7 \mathrm{~Hz}, \mathrm{H} 2\right), 7.40,7.38\left(2 \mathrm{~d}, 1 \mathrm{H}, J_{3,2}=5.7 \mathrm{~Hz}, \mathrm{H} 3\right), 7.27-$ $7.06(\mathrm{~m}, 5 \mathrm{H}, \mathrm{OPh}), 6.26$ (apparent $\left.\mathrm{t}, 1 \mathrm{H}, \mathrm{H} 1^{\prime}\right), 4.68-4.62(\mathrm{~m}, 1 \mathrm{H}$, $\left.\mathrm{H}^{\prime}\right), 4.46-4.20\left(\mathrm{~m}, 4 \mathrm{H}, \mathrm{NH}, \mathrm{H} 4^{\prime}, \mathrm{H} 5^{\prime}, \mathrm{H} 5^{\prime \prime}\right), 3.93-3.86(\mathrm{~m}, 1 \mathrm{H}, \mathrm{H}-\alpha-$ ala), 3.62, $3.60\left(2 \mathrm{~s}, 3 \mathrm{H}, \mathrm{OCH}_{3}\right), 2.53-2.35\left(\mathrm{~m}, 2 \mathrm{H}, \mathrm{H} 2^{\prime} \mathrm{a}, \mathrm{H}^{\prime} \mathrm{b}\right), 1.28$, $1.22 \mathrm{ppm}\left(2 \mathrm{~d}, 3 \mathrm{H}, \mathrm{CH}_{3}\right.$-ala) $;{ }^{13} \mathrm{C}$ NMR $\left(125 \mathrm{MHz}, \mathrm{CDCl}_{3}\right): \delta=174.2-$ 174.1 (CO-ala), 150.6-150.5 (phenyl C), 143.1, 143.0 (C6), 142.8, 142.7 (C8), 142.0, 141.9 (C2), 139.4, 139.3 (C4), 138.2 (C5), 130.0 (phenyl C), 125.5, 125.4 (phenyl C), 120.2, 120.1 (phenyl C), 106.5, 106.4 (C3), 86.0-85.7 (C1', C4'), 70.9, $70.8\left(\mathrm{C}^{\prime}\right), 66.4-65.9\left(\mathrm{C}^{\prime}\right), 52.8$, $52.7\left(\mathrm{OCH}_{3}\right), 50.4$ (C- $\alpha$-ala), 40.6, $40.5\left(\mathrm{C2}^{\prime}\right), 20.9-20.8 \mathrm{ppm}\left(\mathrm{CH}_{3}\right.$-ala); ${ }^{31} \mathrm{P}$ NMR (202 MHz, $\left.\mathrm{CDCl}_{3}\right): \delta=3.23,2.95 \mathrm{ppm}$; HRMS (ESI-): calcd for $\mathrm{C}_{21} \mathrm{H}_{23} \mathrm{CIN}_{4} \mathrm{O}_{7} \mathrm{P}[\mathrm{M}-\mathrm{H}]^{-}$: 509.0998; found: 509.0999 .

2'-Deoxy-6-chloro-3-deazaadenosine-5'-[phenylbis(pivaloyloxymethyliminodiacetyl)] phosphate (3 b): Yield: $40 \% ; \quad R_{\mathrm{f}}=0.64$ $\left(\mathrm{CH}_{2} \mathrm{Cl}_{2} / \mathrm{MeOH}\right.$, 9.5:0.5); ${ }^{1} \mathrm{H}$ NMR (500 MHz, $\left.\mathrm{CDCl}_{3}\right): \delta=8.31(\mathrm{~s}, 0.5 \mathrm{H}$, 
$\mathrm{H} 8$ of one diastereomer), 8.19-8.18 $(2 \mathrm{~d}, 1 \mathrm{H}, \mathrm{H} 2), 8.16(\mathrm{~s}, 0.5 \mathrm{H}, \mathrm{H} 8$ of one diastereomer), 7.43-7.39 $(2 \mathrm{~d}, 1 \mathrm{H}, \mathrm{H} 3), 7.30-7.11(\mathrm{~m}, 5 \mathrm{H}$, $\mathrm{OPh}), 6.29-6.26$ (two sets of apparent $\left.\mathrm{t}, 1 \mathrm{H}, \mathrm{H} 1^{\prime}\right), 5.74-5.69(\mathrm{~m}, 4 \mathrm{H}$, $\left.\mathrm{CH}_{2}-\mathrm{POM}\right), 4.70-4.62\left(\mathrm{~m}, 1 \mathrm{H}, \mathrm{H}^{\prime}\right), 4.38-4.26\left(\mathrm{~m}, 2 \mathrm{H}, \mathrm{H}^{\prime}, \mathrm{H}^{\prime \prime}\right)$, 4.27-4.19 (m, 1 H, H4'), 4.10-3.88 ( $\left.\mathrm{m}, 4 \mathrm{H}, \mathrm{CH}_{2}-\mathrm{IDA}\right), 2.62-2.35(\mathrm{~m}$, $\left.2 \mathrm{H}, \mathrm{H} 2^{\prime} \mathrm{a}, \mathrm{H} 2^{\prime} \mathrm{b}\right), 1.18 \mathrm{ppm}(\mathrm{s}, 18 \mathrm{H}, \mathrm{tBu}) ;{ }^{13} \mathrm{C}$ NMR $\left(125 \mathrm{MHz}, \mathrm{CDCl}_{3}\right)$ : $\delta=177.3,177.2$ (CO-POM), 168.8, 168.7 (CO-IDA), 150.5, 150.4 (phenyl C), 143.2, 143.1 (C6), 142.6, 142.5 (C8), 142.0, 141.9 (C2), 139.5, 139.4 (C4), 138.4, 138.3 (C5), 130.1, 130.0 (phenyl C), 125.6, 125.5 (phenyl C), 120.2, 120.1 (phenyl C), 106.4, 106.3 (C3), 85.885.6 (C1', C4'), 80.3 ( $\left.\mathrm{CH}_{2}-\mathrm{POM}\right), 71.1,70.9\left(\mathrm{C}^{\prime}\right), 66.6,66.3\left(\mathrm{C}^{\prime}\right), 48.2$ $\left(\mathrm{CH}_{2}-\mathrm{IDA}\right), 40.5,40.4\left(\mathrm{C} 2^{\prime}\right), 38.9$ (tBu quaternary $\left.\mathrm{C}\right), 27.0 \mathrm{ppm}$ $(t \mathrm{Bu}){ }^{31} \mathrm{P}$ NMR $\left(202 \mathrm{MHz}, \mathrm{CDCl}_{3}\right): \delta=4.46,4.32 \mathrm{ppm}$; HRMS (ESI + ): calcd for $\mathrm{C}_{33} \mathrm{H}_{43} \mathrm{CIN}_{4} \mathrm{O}_{13} \mathrm{P}[\mathrm{M}+\mathrm{H}]^{+}$: 769.2247; found: 769.2258 .

\section{2'-Deoxy-7-deazaadenosine-5'-[phenyl(methoxy-L-alaninyl)]} phosphate (5a): Yield: 60\%; $R_{\mathrm{f}}=0.35\left(\mathrm{CH}_{2} \mathrm{Cl}_{2} / \mathrm{MeOH}, 9.5: 0.5\right)$; ${ }^{1} \mathrm{H}$ NMR $\left(500 \mathrm{MHz}, \mathrm{CDCl}_{3}\right): \delta=8.25(\mathrm{~s}, 1 \mathrm{H}, \mathrm{H} 2), 7.29-7.10(\mathrm{~m}, 5 \mathrm{H}$, $\mathrm{OPh}), 7.05-7.00\left(2 \mathrm{~d}, 1 \mathrm{H}, J_{8,7}=3.7 \mathrm{~Hz}, \mathrm{H} 8\right), 6.69-6.65$ (two sets of apparent $\mathrm{t}$, overlapped, $\left.\mathrm{H}^{\prime}\right), 6.35-6.33\left(2 \mathrm{~d}\right.$, overlapped, $1 \mathrm{H}, J_{7,8}=$ 3.7 Hz, H7), $5.60\left(\mathrm{~s}, 2 \mathrm{H}, \mathrm{NH}_{2}\right), 4.62-4.45\left(\mathrm{~m}, 2 \mathrm{H}, \mathrm{H3}^{\prime}, \mathrm{NH}\right), 4.30-4.26$ $\left(\mathrm{m}, 2 \mathrm{H}, \mathrm{H} 5^{\prime}, \mathrm{H} 5^{\prime \prime}\right), 4.14-4.10\left(\mathrm{~m}, 1 \mathrm{H}, \mathrm{H} 4^{\prime}\right), 4.01-3.96(\mathrm{~m}, 1 \mathrm{H}, \mathrm{H}-\alpha-$ ala), 3.64, $3.62\left(2 \mathrm{~s}, 3 \mathrm{H}, \mathrm{OCH}_{3}\right), 2.49-2.36\left(\mathrm{~m}, 2 \mathrm{H}, \mathrm{H} 2^{\prime} \mathrm{a}, \mathrm{H} 2^{\prime} \mathrm{b}\right), 1.31$, $1.28 \mathrm{ppm}\left(2 \mathrm{~d}, 3 \mathrm{H}, \mathrm{CH}_{3}\right.$-ala); ${ }^{13} \mathrm{C}$ NMR $\left(125 \mathrm{MHz}, \mathrm{CDCl}_{3}\right): \delta=173.8-$ 173.7 (CO-ala), 156.5 (C6), 151.5, 151.4 (C2), 150.3, 150.2 (phenyl C), 150.0, 149.9 (C4), 129.4 (phenyl C), 124.7 (phenyl C), 121.3, 121.2 (C8), 119.8-119.7 (phenyl C), 103.3, 103.2 (C5), 98.9 (C7), 83.9, 83.8 $\left(\mathrm{C} 4^{\prime}\right), 82.8,82.7\left(\mathrm{C}^{\prime}\right), 70.9,70.8\left(\mathrm{C}^{\prime}\right), 66.2,65.9\left(\mathrm{C}^{\prime}\right), 52.2,52.1$ $\left(\mathrm{OCH}_{3}\right), 49.9,49.8$ (C- $\alpha$-ala), $39.6\left(\mathrm{C}^{\prime}\right), 20.4,20.3$ ppm $\left(\mathrm{CH}_{3}\right.$-ala $)$; ${ }^{31} \mathrm{P}$ NMR $\left(202 \mathrm{MHz}, \mathrm{CDCl}_{3}\right): \delta=3.26,2.99 \mathrm{ppm}$; HRMS (ESI+): calcd for $\mathrm{C}_{21} \mathrm{H}_{27} \mathrm{~N}_{5} \mathrm{O}_{7} \mathrm{P}[\mathrm{M}+\mathrm{H}]^{+}$: 492.1642; found: 492.1644 .

2'-Deoxy-7-deazaadenosine-5'-[phenylbis(pivaloyloxymethyliminodiacetyl)] phosphate $(5 \mathrm{~b})$ : Yield: $25 \% ; R_{\mathrm{f}}=0.26\left(\mathrm{CH}_{2} \mathrm{Cl}_{2} / \mathrm{MeOH}\right.$, 9.65:0.35); ${ }^{1} \mathrm{H}$ NMR $\left(500 \mathrm{MHz}, \mathrm{CDCl}_{3}\right): \delta=8.26(\mathrm{~s}, 1 \mathrm{H}, \mathrm{H2}), 7.30-7.16$ $\left(\mathrm{m}, 5.5 \mathrm{H}, \mathrm{OPh}, \mathrm{H} 8\right.$ of one diastereomer), $7.02\left(\mathrm{~d}, 0.5 \mathrm{H}, \mathrm{J}_{8,7}=3.3 \mathrm{~Hz}\right.$, $\mathrm{H} 8$ of one diastereomer), 6.70-6.68 (two sets of apparent t, overlapped, $\left.\mathrm{H}^{\prime}{ }^{\prime}\right), 6.39-6.38(2 \mathrm{~d}, 1 \mathrm{H}, \mathrm{H} 7), 5.73-5.63\left(\mathrm{~m}, 6 \mathrm{H}, \mathrm{CH}_{2}-\mathrm{POM}\right.$, $\left.\mathrm{NH}_{2}\right), 4.65-4.58\left(\mathrm{~m}, 1 \mathrm{H}, \mathrm{H3} 3^{\prime}\right), 4.35-4.33\left(\mathrm{~m}, 2 \mathrm{H}, \mathrm{H}^{\prime}, \mathrm{H}^{\prime \prime}\right), 4.12-3.92$ (m, $\left.5 \mathrm{H}, \mathrm{H} 4^{\prime}, \mathrm{CH}_{2}-\mathrm{IDA}\right), 2.59-2.40\left(\mathrm{~m}, 2 \mathrm{H}, \mathrm{H}^{\prime} \mathrm{a}, \mathrm{H}^{\prime} \mathrm{b}\right), 1.25,1.18 \mathrm{ppm}$ $(2 \mathrm{~s}, 18 \mathrm{H}, t \mathrm{Bu}) ;{ }^{13} \mathrm{C}$ NMR $\left(125 \mathrm{MHz}, \mathrm{CDCl}_{3}\right): \delta=177.3,177.2$ (COPOM), 168.8, 168.7 (CO-IDA), 156.9 (C6), 151.7, 151.6 (C2), 150.7150.5 (phenyl C, C4), 129.9 (phenyl C), 125.4 (phenyl C), 121.9121.6 (C8), 120.2 (phenyl C), 103.7, 103.6 (C5), 99.4-99.2 (C7), 84.3$84.2\left(\mathrm{C}^{\prime}\right), 83.2-82.9\left(\mathrm{C1}^{\prime}\right), 80.1,80.0\left(\mathrm{CH}_{2}-\mathrm{POM}\right), 71.2-71.1\left(\mathrm{C}^{\prime}\right)$, 66.8-66.3 (C5'), 48.0-47.9 ( $\mathrm{CH}_{2}-$ IDA), 40.1, $39.9\left(\mathrm{C}^{\prime}\right), 38.9$ (tBu quaternary C), 27.5, $26.9 \mathrm{ppm}(t \mathrm{Bu}) ;{ }^{31} \mathrm{P}$ NMR $\left(121 \mathrm{MHz}, \mathrm{CDCl}_{3}\right): \delta=4.08$, 3.94 ppm; HRMS (ESI+): calcd for $\mathrm{C}_{33} \mathrm{H}_{45} \mathrm{~N}_{5} \mathrm{O}_{13} \mathrm{P}[M+\mathrm{H}]^{+}$: 750.2746; found: 750.2729 .

Antiviral assays: The compounds were evaluated against the following viruses: HSV-1 strain KOS, thymidine kinase deficient $\left(\mathrm{TK}^{-}\right)$ HSV-1 KOS strain resistant to ACV (ACV'), HSV-2 strain G, vaccinia virus Lederle strain, varicella-zoster virus (VZV) strain Oka, $\mathrm{TK}^{-} \mathrm{VZV}$ strain 07-1, and human cytomegalovirus (HCMV) strains AD-169 and Davis. The antiviral assays were based on inhibition of virus-induced cytopathicity or plaque formation in human embryonic lung (HEL) fibroblasts. Confluent cell cultures in microtiter 96-well plates were inoculated with $100 \mathrm{CCID}_{50}$ of virus (with $1 \mathrm{CCID}_{50}$ being the virus dose required to infect $50 \%$ of the cell cultures) or with 20 plaque-forming units (PFU; VZV) in the presence of varying concentrations of the test compounds. Viral cytopathicity or plaque formation (VZV) was recorded as soon as it reached completion in the control virus-infected cell cultures that were not treated with the test compounds. Antiviral activity was expressed as the $\mathrm{EC}_{50}$ value or effective compound concentration (expressed in micromolar concentrations) required for decreasing virus-induced cytopathogenicity or viral plaque formation by $50 \%$.

Cytostatic/toxicity assays: Cytotoxicity measurements were based on the inhibition of cell growth. HEL cells were seeded at a rate of $5 \times 10^{3}$ cells per well into 96-well microtiter plates and allowed to proliferate for $24 \mathrm{~h}$. Medium containing different concentrations of the test compounds was then added. After three days of incubation at $37^{\circ} \mathrm{C}$, the cell number was determined with a Coulter counter. The cytostatic concentration (expressed in micromolar concentrations) was calculated as the $\mathrm{CC}_{50}$ value or the compound concentration required for decreasing cell proliferation by $50 \%$ relative to the number of cells in the untreated controls. $C_{50}$ values were estimated from graphic plots of the number of cells (percentage of control) as a function of the concentration of the test compounds. Alternatively, cytotoxicity of the test compounds was expressed as the minimum cytotoxic concentration (MCC) or the compound concentration that caused a microscopically detectable alteration of cell morphology.

Stability assay in human serum: The experiment was carried out by dissolving ProTide $\mathbf{1} \mathbf{a}$ and $\mathbf{1} \mathbf{b}(5-6 \mathrm{mg})$ in $\left[\mathrm{D}_{6}\right] \mathrm{DMSO}(0.06 \mathrm{~mL})$ and $\mathrm{D}_{2} \mathrm{O}(0.18 \mathrm{~mL})$. After recording the ${ }^{31} \mathrm{P}$ NMR spectra at $37^{\circ} \mathrm{C}$ as a control, human serum $(0.35 \mathrm{~mL})$ was added to the sample. Next, a series of ${ }^{31} \mathrm{P}$ NMR spectra were recorded at $37^{\circ} \mathrm{C}$ over a period of $14 \mathrm{~h}$. The ${ }^{31} \mathrm{P}$ NMR data were processed and analyzed with the Bruker Topspin 2.1 program.

\section{Acknowledgements}

This work was financed by FWO and KU Leuven grants GOA and IDO. We are indebted to Prof. Jef Rozenski (KU Leuven) for providing HRMS data. Mass spectrometry was made possible by the support of the Hercules Foundation of the Flemish Government (grant 20100225-7). We thank Luc Baudemprez for NMR technical assistance, Frieda De Meyer, Lies Van den Heurck, Steven Carmans, and Anita Camps for assistance with the antiviral assays, and Chantal Biernaux for excellent editorial help.

Keywords: antiviral agents • drug delivery • nucleosides phosphoramidates $\cdot$ protecting groups

[1] a) E. De Clercq, Adv. Virus Res. 2009, 73, 1-53; b) G. Antonelli, O. Turriziani, Int. J. Antimicrob. Agents 2012, 40, 95-102.

[2] E. De Clercq, Med. Res. Rev. 2005, 25, 1-20.

[3] H. S. Allaudeen, J. W. Kozarich, J. R. Bertino, E. De Clercq, Proc. Natl. Acad. Sci. USA 1981, 78, 2698-2702.

[4] J. A. Fyfe, Mol. Pharmacol. 1982, 21, 432-437.

[5] a) J. Balzarini, Pharm. World Sci. 1994, 16, 113-126; b) C. R. Wagner, S. L. Chang, G. W. Griesgraber, H. Song, E. J. McIntee, C. L. Zimmerman, Nucleosides Nucleotides 1999, 18, 913-919; c) S. Chang, G. W. Griesgraber, P. J. Southern, C. R. Wagner, J. Med. Chem. 2001, 44, 223-231.

[6] J. Balzarini, H. Egberink, K. Hartmann, D. Cahard, T. Vahlenkamp, H. Thormar, E. De Clercq, C. McGuigan, Mol. Pharmacol. 1996, 50, 1207 1213.

[7] B. A. J. Wilber, J. J. Docherty, J. Gen. Virol. 1994, 75, $1743-1747$.

[8] C. R. Wagner, V. V. Iyer, E. J. Mclntee, Med. Res. Rev. 2000, 20, 417-451.

[9] K. G. Devine, C. McGuigan, T. J. O'Connor, S. R. Nicholls, D. Kinchington, AIDS 1990, 4, 371-373.

[10] D. Cahard, C. McGuigan, J. Balzarini, Mini Rev. Med. Chem. 2004, 4, 371 381.

[11] D. P. Drontle, C. R. Wagner, Mini Rev. Med. Chem. 2004, 4, 409-419. 
[12] Y. Mehellou, J. Balzarini, C. McGuigan, ChemMedChem 2009, 4, 1779 1791.

[13] S. A. Harris, C. McGuigan, G. Andrei, R. Snoeck, E. De Clercq, J. Balzarini, Antiviral Chem. Chemother. 2001, 12, 293-300.

[14] A. Giraut, X. P. Song, M. Froeyen, P. Marliere, P. Herdewijn, Nucleic Acids Res. 2010, 38, $2541-2550$.

[15] D. Farquhar, D. N. Srivastva, N. J. Kattesch, P. P. Saunders, J. Pharm. Sci. 1983, 72, 324-325.

[16] a) L. Naesens, N. Bischofberger, P. Augustijns, P. Annaert, G. van den Mooter, M. N. Arimilli, C. U. Kim, E. De Clercq, Antimicrob. Agents Chemother. 1998, 42, 1568-1573; b) H. B. Fung, E. A. Stone, F. J. Piacenti, Clin. Ther. 2002, 24, 1515-1548.

[17] a) J. E. Starrett, Jr., D. R. Tortolani, M. J. Hitchcock, J. C. Martin, M. M. Mansuri, Antiviral Res. 1992, 19, 267-273; b) L. Naesens, J. Balzarini, N Bischofberger, E. De Clercq, Antimicrob. Agents Chemother. 1996, 40 $22-28$; c) P. Annaert, R. Kinget, L. Naesens, E. De Clercq, P. Augustijns, Pharm. Res. 1997, 14, 492-496; d) P. Barditch-Crovo, J. Toole, C. W. Hendrix, K. C. Cundy, D. Ebeling, H. S. Jaffe, P. S. Lietman, J. Infect. Dis. 1997 $176,406-413$

[18] J. Rautio, H. Kumpulainen, T. Heimbach, R. Oliyai, D. Oh, T. Jarvinen, J. Savolainen, Nat. Rev. Drug Discovery 2008, 7, 255-270.

[19] a) J. Balzarini, A. Holy, J. Jindrich, L. Naesens, R. Snoeck, D. Schols, E. De Clercq, Antimicrob. Agents Chemother. 1993, 37, 332-338; b) E. De Clercq, Antiviral Res. 2007, 75, 1-13.

[20] a) L. L. Siu, D. D. Von Hoff, A. Rephaeli, E. Izbicka, C. Cerna, L. Gomez, E. K. Rowinsky, S. G. Eckhardt, Invest. New Drugs 1998, 16, 113-119; b) T. Reid, F. Valone, W. Lipera, D. Irwin, W. Paroly, R. Natale, S. Sreedharan, H. Keer, B. Lum, F. Scappaticci, A. Bhatnagar, Lung Cancer 2004, 45, 381 386.

[21] N. Korsisaari, D. J. Rossi, K. Luukko, K. Huebner, M. Henkemeyer, T. P. Makela, Mol. Cell. Biol. 2003, 23, 3929-3935.

[22] a) T. W. Abraham, C. R. Wagner, Nucleosides Nucleotides 1994, 13, 1891 1903; b) E. J. Mclntee, R. P. Remmel, R. F. Schinazi, T. W. Abraham, C. R. Wagner, J. Med. Chem. 1997, 40, 3323-3331.
[23] T. W. Abraham, T. I. Kalman, E. J. McIntee, C. R. Wagner, J. Med. Chem 1996, 39, 4569-4575

[24] O. Adelfinskaya, P. Herdewijn, Angew. Chem. 2007, 119, 4434-4436 Angew. Chem. Int. Ed. 2007, 46, 4356-4358.

[25] M. Maiti, S. Michielssens, N. Dyubankova, M. Maiti, E. Lescrinier, A. Ceulemans, P. Herdewijn, Chem. Eur. J. 2012, 18, 857-868.

[26] A. C. Benniston, P. Gunning, R. D. Peacock, J. Org. Chem. 2005, 70, $115-$ 123.

[27] B. P. Bandgar, R. J. Sarangdhar, S. Viswakarma, F. A. Ahamed, J. Med. Chem. 2011, 54, $1191-1201$.

[28] Y. Feng, J. K. Coward, J. Med. Chem. 2006, 49, 770-788.

[29] D. M. Lehsten, D. N. Baehr, T. J. Lobl, A. R. Vaino, Org. Process Res. Dev. 2002, 6, 819-822.

[30] a) C. McGuigan, R. N. Pathirana, N. Mahmood, K. G. Devine, A. J. Hay, Antiviral Res. 1992, 17, $311-321$; b) C. McGuigan, R. N. Pathirana, J. Balzarini, E. De Clercq, J. Med. Chem. 1993, 36, 1048- 1052.

[31] a) Y. Mizuno, T. Itoh, K. Saito, Chem. Pharm. Bull. 1964, 12, 866-872; b) F. Seela, H. Rosemeyer, S. Fischer, Helv. Chim. Acta 1990, 73, 1602 1611 ; c) C. Crey-Desbiolles, J. Lhomme, P. Dumy, M. Kotera, J. Am. Chem Soc. 2004, 126, $9532-9533$.

[32] E. P. Brass, Pharmacol. Rev. 2002, 54, 589-598.

[33] S. Vittori, D. Dal Ben, C. Lambertucci, G. Marucci, R. Volpini, G. Cristalli, Curr. Med. Chem. 2006, 13, 3529-3552.

[34] M. J. Sofia, W. S. Chang, P. A. Furman, R. T. Mosley, B. S. Ross, J. Med. Chem. 2012, 55, $2481-2531$.

[35] a) M. Derudas, D. Carta, A. Brancale, C. Vanpouille, A. Lisco, L. Margolis, J. Balzarini, C. McGuigan, J. Med. Chem. 2009, 52, 5520-5530; b) C. McGuigan, P. Murziani, M. Slusarczyk, B. Gonczy, J. Vande Voorde, S. Liekens, J. Balzarini, J. Med. Chem. 2011, 54, 7247-7258.

Received: January 24, 2013

Revised: March 15, 2013

Published online on II, 0000 


\section{FULL PAPERS}

M. Maiti, L. Persoons, G. Andrei,

R. Snoeck, J. Balzarini, P. Herdewijn*

Synthesis and Anti-herpetic Activity of Phosphoramidate ProTides

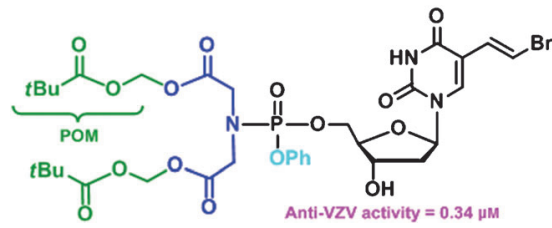

Key to membrane permeability: The introduction of the pivaloyloxymethyl (POM) moiety as a carboxyl protecting group has shown promise in the design of antiviral phosphoramidate prodrugs for the intracellular delivery of nucleoside monophosphates. Antiviral data also support the substitution of a primary amine with a secondary amine in the intracellular delivery of ProTide analogues. 